Review

\title{
Non-shivering Thermogenesis Signalling Regulation and Potential Therapeutic Applications of Brown Adipose Tissue
}

\author{
Zhengyan Zhang1,2\#, Di Yang1,2\#, Junwei Xiang1,2, Jingwen Zhou1,2, Hua Cao3, Qishi Che4, Yan Bai5, Jiao \\ $\mathrm{Guo}^{2 \bowtie}$, Zhengquan Su ${ }^{1,2 \bowtie}$ \\ 1. Guangdong Engineering Research Center of Natural Products and New Drugs, Guangdong Provincial University Engineering Technology Research Center \\ of Natural Products and Drugs, Guangdong Pharmaceutical University, Guangzhou 510006, China \\ 2. Guangdong Metabolic Diseases Research Centre of Integrated Chinese and Western Medicine, Guangdong Pharmaceutical University, Guangzhou 510006, \\ China \\ 3. Guangdong Cosmetics Engineering \& Technology Research Center, School of Chemistry and Chemical Engneering, Guangdong Pharmaceutical University, \\ Guangzhou 510006, China \\ 4. Guangzhou Rainhome Pharm \& Tech Co., Ltd., Guangzhou 510663, China \\ 5. School of Public Health, Guangdong Pharmaceutical University, Guangzhou 510310, China \\ \# Co-first author \\ $\square$ Corresponding authors: E-mail: suzhq@scnu.edu.cn (Z.-Q.S.) and gyguoyz@163.com (J.G.); Tel.: +86-20-3935-2067; Fax: +86-20-3935-2067.
}

( $)$ The author(s). This is an open access article distributed under the terms of the Creative Commons Attribution License (https://creativecommons.org/licenses/by/4.0/). See http://ivyspring.com/terms for full terms and conditions.

Received: 2021.03.11; Accepted: 2021.06.23; Published: 2021.07.13

\begin{abstract}
In mammals, thermogenic organs exist in the body that increase heat production and enhance energy regulation. Because brown adipose tissue (BAT) consumes energy and generates heat, increasing energy expenditure via BAT might be a potential strategy for new treatments for obesity and obesity-related diseases. Thermogenic differentiation affects normal adipose tissue generation, emphasizing the critical role that common transcriptional regulation factors might play in common characteristics and sources. An understanding of thermogenic differentiation and related factors could help in developing ways to improve obesity indirectly or directly through targeting of specific signalling pathways. Many studies have shown that the active components of various natural products promote thermogenesis through various signalling pathways. This article reviews recent major advances in this field, including those in the cyclic adenosine monophosphate-protein kinase A (cAMP-PKA), cyclic guanosine monophosphate-GMPdependent protein kinase G (cGMP-AKT), AMP-activated protein kinase (AMPK), mammalian target of rapamycin (mTOR), transforming growth factor- $\beta$ /bone morphogenic protein (TGF- $\beta / B M P)$, transient receptor potential (TRP), Wnt, nuclear factor-K-light-chain-enhancer of activated B cells (NF-KB), Notch and Hedgehog $(\mathrm{Hh})$ signalling pathways in brown and brown-like adipose tissue. To provide effective information for future research on weight-loss nutraceuticals or drugs, this review also highlights the natural products and their active ingredients that have been reported in recent years to affect thermogenesis and thus contribute to weight loss via the above signalling pathways.
\end{abstract}

Key words: Thermogenesis; Signalling Pathways; Obesity; Brown Adipose Tissue; Natural products

\section{Introduction}

Obesity has increasingly become a burden on the human health system. Effective treatment of obesity greatly reduces the morbidity of other metabolic diseases [1]. Obesity is the excess storage of metabolic energy. Energy homeostasis is closely related to the active function of adipose tissue. Adipose tissue in animals consists mainly of brown adipose tissue
(BAT) and white adipose tissue (WAT). BAT includes classic BAT and recently discovered beige adipose tissue, which resists cold and obesity through adaptive heat production, known as non-shivering thermogenesis. Non-shivering thermogenesis is regulated by multiple signalling pathways. Thermogenic adipocytes, including brown adipocytes 
and beige adipocytes, have been shown to be prolific in human infants and adults [2]. Increasingly, it is becoming clear that BAT and BAT-like tissues have significant effects on total body metabolism in humans.

Signalling pathway-mediated control of the adipocyte lineage has been studied extensively. Thermogenesis regulation has long been assumed to mainly occur through typical pathways, such as the cyclic adenosine monophosphate-protein kinase A (cAMP-PKA) signalling pathway in the sympathetic nervous system (SNS). AMP-activated protein kinase (AMPK) promotes brown adipocyte differentiation and thermogenesis. mammalian target of rapamycin (mTOR), which antagonizes AMPK, also regulates brown adipocyte differentiation and thermogenesis. Transient receptor potential (TRP) channels can affect BAT thermogenesis by mediating $\mathrm{Ca}^{2+}$ influx in different ways. Other signalling pathways, including the Wnt, nuclear factor-k-light-chain-enhancer of activated B cells (NF-kB), Notch and Hedgehog (Hh) signalling pathway, can also influence BAT differentiation and thermogenesis.

To realize and fully utilize the potential of these cellular metabolic functions, the evolutionary history and different regulatory mechanisms of thermogenesis should be explored. This review illustrates the current findings on all the thermogenesis-related signalling pathways that have been studied in recent years. In this paper, the role of specific signalling pathways in adipose tissue function regulation and their molecular mechanism are reviewed. In addition, this review illustrates the potential therapeutic applications, mainly focusing on natural products and their active ingredients that might improve obesity by affecting related signalling pathways.

\section{UCP1-mediated thermogenesis and transcriptional regulators in BAT}

UCP1 is considered the origin of adaptive thermogenesis in BAT. UCP1 lowers the proton gradient by uncoupling the respiratory chain and facilitates synthesis of cyclic adenosine monophosphate (cAMP) which promotes thermogenesis capacity in mitochondria. Therefore, activation of $\mathrm{UCP} 1$ is an important protective mechanism against obesity and related metabolic diseases.

When adipocytes are activated, the first step is the release of norepinephrine (NE) by the SNS. Subsequently, adrenergic receptors (mainly $\beta 1$ and $\beta 3$ subtypes) are activated, therefore, cAMP increases greatly and leads to activation of PKA. PKA induces lipolysis, and releases free fatty acids (FFAs) that stimulate UCP1 expression in the inner mitochondrial membrane. UCP1 enables the active transport of protons across the semipermeable membrane by the electron transport chain to decrease the proton concentration gradient, thereby releasing energy instead of through ADP phosphorylation. Activated UCP1 rapidly induces movement of protons back into the mitochondrial matrix, which in turn reduces hydrogen levels, activates respiratory pathways and oxidizes fatty acids (FAs). In this situation, the proton pathway is not used to phosphorylate ADP to generate heat [3].

Although UCP1 is a decisive factor associated with thermogenic activity, thermogenesis is also influenced by many other factors in BAT, such as oxidative phosphorylation, FA metabolism, lipolysis and mitochondrial biogenesis [4]. Accordingly, the biological significance of improving UCP1 transcriptional levels in BAT is also determined by other elements. The synthesis of rodent $\mathrm{UCP} 1$ requires other hormones in addition to NE, such as triiodothyronine, leptin, insulin, glucocorticoid, and corticosterone [5].

Transcriptional cascades that control the process of brown and beige adipocyte development induce a number of regulators. Element-binding proteins (CEBPs) and peroxisome proliferator-activated receptor $\gamma$ (PPAR $\gamma$ ) are the major moderators that control the fate of brown adipocytes [6], and PPARY coactivator-1a (PGC-1a) is the major thermogenesis factor in adipocytes [7]. Additionally, PR domain zinc finger protein (PRDM16) regulates PPARY, CEBPs and PGC-1a, and bilaterally determines brown adipocyte differentiation [8]. A number of upstream regulators of PRDM16, such as EBF2 and EHMT1, positively induce browning of adipocytes $[9,10]$, and negative regulators, including TLE3 and miRNAs, lead to the opposite results [11]. Forkhead box C2 (FoxC2) also induces browning of WAT in response to leptin-STAT3-PRDM16 signalling [12]. In summary, many transcription factors in BAT, such as PGC-1a, PRDM16, PPARY, CEBPs and FoxC2, control thermogenesis in BAT or beige fat via UCP1-mediated mechanisms. How synergy and negative feedback occur among these factors or whether the coexisting thermogenesis signalling pathways in vivo have causal relationships with these mechanisms is unknown, surely, these pathways must have common connections.

\section{Major advances in thermogenesis signalling pathways in BAT}

In the past few decades, numerous studies have identified positive or negative regulators involved in the development of brown adipocytes [13]. $\beta$-AR signalling is a dominant pathway involved in energy 
balance and thermogenesis that contributes to thermogenesis in BAT and browning of WAT. Furthermore, previously unobserved signalling pathways have recently been reported. Here, we review recent studies on signalling pathways that are responsible for controlling thermogenesis in BAT and beige fat.

\section{CAMP-PKA signalling pathway}

The cAMP-PKA signalling pathway is the most classical pathway in thermogenesis and has been studied in depth. UCP1 activation and transcription in BAT are regulated by NE, which is released from the SNS. NE binds to $\beta$-AR through the p38 mitogen-activated protein kinase (p38 MAPK) signalling pathway to activate AC coupled to $G$ proteins (i.e., guanine nucleotide-binding regulatory proteins, including GDPa, GDP $\beta$, and GDP $\gamma$ ). This increases the concentration of intracellular cAMP, which is a secondary messenger in the cell. As a result, PKA is phosphorylated, followed by p38 MAPK activation. This activation leads to hormone-sensitive triglyceride lipase (HSL) phosphorylation, which ultimately promotes decomposition of triglycerides stored in lipid droplets into glycerol and FA and activates UCP1expression.

There are two classical pathways by which PKA regulates thermogenesis. In one pathway, UCP1 expression is upregulated by PKA in a p38 MAPK-dependent manner. PKA activates two important downstream substrates, PGC-1a and activating transcription factor-2 (ATF-2). On the one hand, activation of p38 MAPK enables phosphorylation and activation of ATF-2 via cAMP in response to CREB to promote PGC-1a and UCP1 transcription in BAT. In addition, activation of p38 MAPK phosphorylates PGC-1a and activates PGC-1a to induce UCP1 transcription by binding to PPARY and the UCP1 promoter. In the p38 MAPK-independent process, CREB is phosphorylated by PKA and binds with cAMP to directly promote UCP1 and PGC-1a expression, promoting the occurrence of beige fat and enhancing thermogenesis [14].

In the other pathway, lipohydrolysis is promoted. FAs are both substrates and activators of thermogenesis in BAT. PKA can activate HSL and adipose triglyceride lipase (ATGL), promoting its lipolysis function, which increases the release of FFAs for mitochondrial utilization, thereby regulating BAT thermogenesis. Perilipin (PLIN) exists on the surface of lipid droplets, and can block the contact between lipid droplets and lipase, acting as a barrier to the lipid decomposition reaction. PKA phosphorylation of PLIN removes this barrier effect, allowing lipid droplets to fully contact ATGL and initiating lipohydrolysis [15].

In addition to the classical methods, many new methods by which cAMP-PKA regulates BAT thermogenesis have recently been found. Under endoplasmic reticulum stress, PKA phosphorylates inositol-requiring enzyme-1a (IRE-1) and IRE-1 subsequently activates $\mathrm{X}$-box binding protein-1 (XBP-1) which has transcription factor activity and can upregulate UCP1 expression and increase BAT thermogenesis [16]. Silent information regulator-1 (Sirt-1) is an important transcriptional regulator. PKA activates SIRT-1, which in turn activates PGC-1. PGC-1 upregulates the expression of thermogenesisrelated genes and thereby increases thermogenesis [17]. Adaptor protein containing the pleckstrin homology domain, phosphotyrosine binding domain and leucine zipper motif (APPL1), stimulated by cAMP, travels from the cytoplasm to the nucleus and interacts directly with histone deacetylase 3 (HDAC3) to mediate UCP1 expression in cultured brown fat cells [18]. The microbiota has also been found to promote thermogenesis by activating cAMP-PKA signalling [19]. A recent study confirmed that outer mitochondrial membrane-located AIDA is phosphorylated by PKA, translocates to the intermembrane space and activates UCP1 expression and thermogenesis [20].

Multiple factors can also negatively regulate thermogenesis by inhibiting the cAMP-PKA pathway. Insulin-AKT signalling is inhibited by phosphodiesterase (PDE), which is a classical pathway that negatively regulates lipohydrolysis. The cGMP-AMP (cGAMP) synthase-stimulator of interferon genes (cGAS-STING) pathway activated by mitochondrial stress inhibits PKA signal transduction by activating PDE, thus inhibiting BAT thermogenesis [21]. RNA-binding protein quaking (QKI), induced by CREB, can reduce the stability, nuclear export, and translation of mRNAs encoding UCP1 and PGC1a, thereby restricting BAT energy expenditure [22].

cAMP-PKA is the most intensively studied signalling pathway in BAT thermogenesis. It plays a key regulatory role in lipid metabolism and is an important target for treatment of lipid metabolism disorders and related diseases. Many regulatory factors based on this pathway are still being discovered, and it is hoped that understanding of this pathway can be continuously improved through future studies, to provide a research basis for treatment targeting this signalling pathway (Figure 1). 


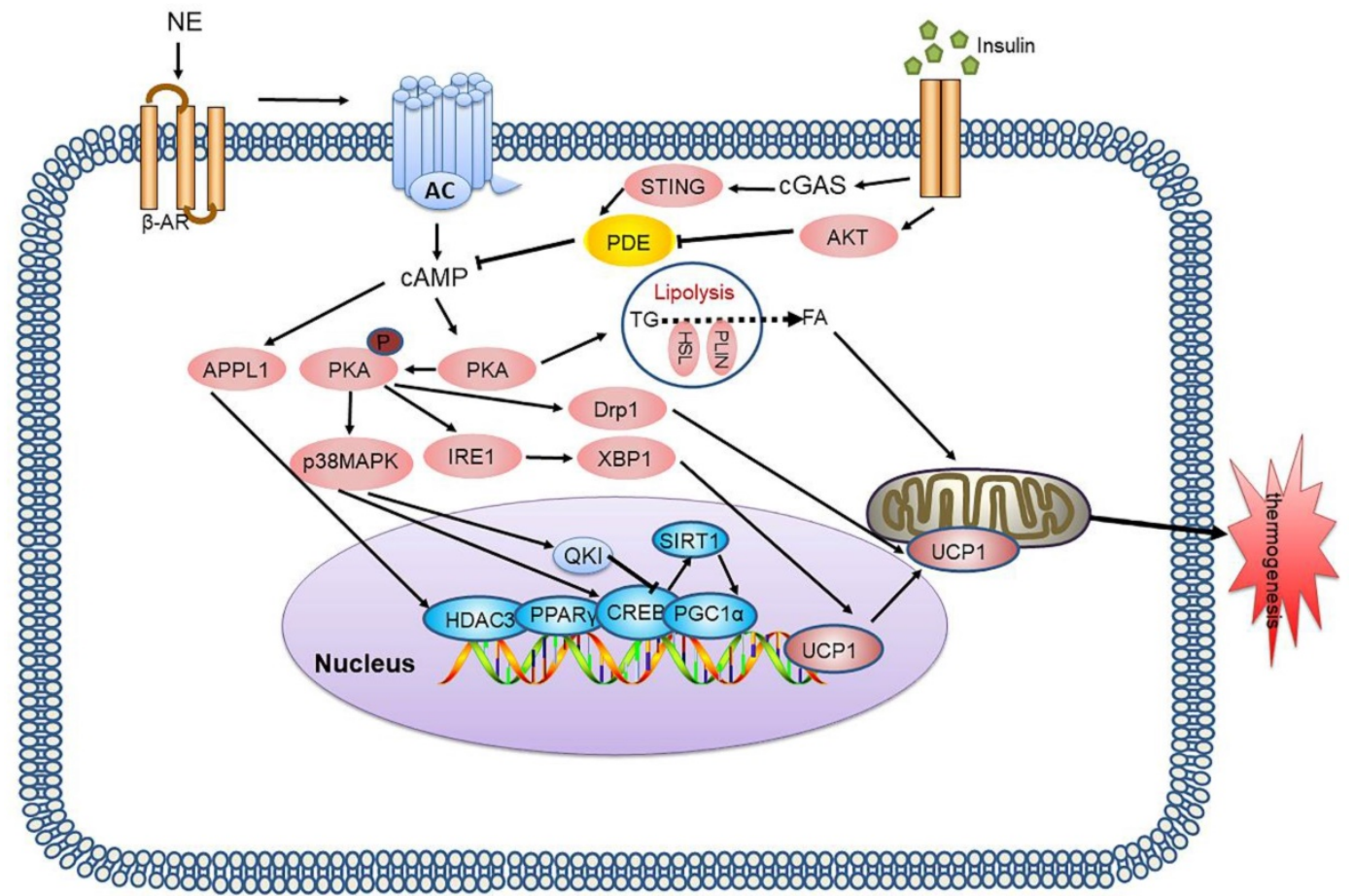

Figure 1. CAMP-PKA signalling pathway and its signalling networks. Sympathetic neurons release NE and activate $\beta$-AR on adipocytes, thereby activating AC which catalyses CAMP, resulting in PKA phosphorylation and activation of HSL and other components of the lipolysis pathway. PKA also activates the p38 MAPK pathway, which leads to increased UCPI transcription and the expression of other prothermogenic genes. New regulatory factors affecting thermogenesis via the cAMP-PKA pathway are also continuously being discovered, including IRE-1, APPLI, and Drpl. The cGAS-STING pathway activated by mitochondrial stress inhibits PKA signal transduction by activating PDE, thus inhibiting BAT thermogenesis. NE: norepinephrine; $\beta$-AR: $\beta$-adrenergic receptor; AC: adenylyl cyclase; cAMP: cyclic adenosine monophosphate; PKA: protein kinase A; HSL: hormone-sensitive triglyceride lipase; p38 MAPK: p38 mitogen-activated protein kinase; UCP1: uncoupling protein 1; IRE-1: inositol-requiring enzyme-1 $\alpha$; APPL1: adaptor protein containing the pleckstrin homology domain, phosphotyrosine binding domain and leucine zipper motif; Drp1: dynamin-related protein 1; cGAS: cGMP-AMP (cGAMP) synthase; STING: stimulator of interferon genes; PDE: phosphodiesterase; BAT: brown adipose tissue

\section{cGMP-AKT signalling}

Apart from cAMP, cGMP is also an important second messenger. cGMP is produced by guanylyl cyclases (GCs) that are activated by nitric oxide (NO) or natriuretic peptides (NPs). cGMP activates GMP-dependent protein kinase G (PKG/AKT), and plays an important role in BAT thermogenesis [23]. GCs can be divided into soluble and membrane bound proteins. Soluble GCs (sGCs) are heterodimers made up of a and $\beta$ subunits, and are activated by NO. Nitric oxide synthases mediate endogenous NO production by converting L-arginine into citrulline, and $\mathrm{NO}$, nitrate $\left(\mathrm{NO}^{3-}\right)$ and nitrite $\left(\mathrm{NO}^{2-}\right)$ are inert end products of NO metabolism [24, 25].

Many studies have demonstrated that the NO-cGMP-dependent pathway regulates mitochondrial biogenesis and energy balance. Linda focused on the sGC-dependent pathway, and found that an sGC pharmacological stimulator improves obesity and leads to positive metabolic changes [26]. Becerril et al. showed that ablation of inducible NOS improved the energy balance in ob/ob mice by increasing thermogenesis [27]. Gursimran suggested that nonburning (low-dose) UVR inhibits WAT generation and steatosis through skin release of NO [28]. NO has been shown to directly prevent mitochondrial respiration by occupying the oxygenation site of cytochrome oxidase [29].

The NP system consists of three different ligand-receptor pairs, namely atrial natriuretic peptide (ANP), brain natriuretic peptide (BNP), and C-type natriuretic peptide (CNP), and the corresponding receptors (NPRs): NPRA, NPRB, and NPRC [30]. NP binds to NPR and induces cGMP production, and due to their GC activity, NPRA and NPRB are also referred to as particulate GCs. The action of ANP and BNP is mediated by the receptor NPRA, while NPRC binds to ANP and BNP, removing them from circulation [31] (Figure 2).

Recent studies have shown that CNP activates the BAT thermogenesis program in mouse and human adipocytes via p38 MAPK [32], and that ANP directly increases mitochondrial uncoupling and thermogene expression in human WAT and BAT [33]. Anja et al. studied the effect of an optimized designer natriuretic peptide (CD-NP) on adipose tissue in mice and found that WAT browning increased in mice treated with CD-NP for 10 days. However, long-term treatment with CD-NP led to weight gain, reduced glucose tolerance, reduced lipolytic activity, and cirrhosis [34]. The effects of NPs vary with treatment duration, and the mechanism is unknown. cGMP-regulated pathways remain less studied, and 
many questions remain about the mechanisms that we now know about.

\section{AMPK signalling pathway}

AMPK, a ubiquitously distributed serine/ threonine protein kinase, is a crucial regulator involved in multiple metabolic pathways, is highly expressed in both the brain and BAT, and regulates thermogenesis. AMPK activation is determined by its heterotrimeric structure, comprising of a catalytic subunit ( $\alpha 1$ and $\alpha 2)$ and two regulatory subunits ( $\beta$ and $\gamma$ ) [35]. AMPK has an important role in improving glucose uptake, FA oxidation, and mitochondrial biogenesis to treat obesity and other metabolic diseases [36]. AMPK activation rewires metabolism to reduce ATP consumption and increase ATP production to favour energy balance [37].

In BAT, AMPK activation facilitates glucose and FA uptake, improves mitochondrial function and FA oxidation, increases non-shivering thermogenesis and inhibits fat and cholesterol synthesis in brown and beige adipocytes. Zhao, et al. showed that AMPK deficiency decreases progenitor cell density, inhibits brown adipocyte differentiation, and promotes fibrous cell differentiation [38]. Wu et al. found that adipocyte AMPKa deficiency inhibits thermogenesis and energy consumption when stimulated by cold and $\beta-A R$, resulting in obesity and related metabolic disease [39]. NE increases PGC-1a expression in the same manner as activation of AMPK signalling in the presence of AMPK $\beta 1$ [40].

AMPK is also important for maintaining the normal function of BAT mitochondria. Mitochondrial $\mathrm{Ca}^{2+}$ plays an important role in regulating mitochondrial activity, and the mitochondrial calcium uniporter (MCU) is the most critical channel that mediates $\mathrm{Ca}^{2+}$ uptake. A recent study reported that the expression levels of MCU complex members were increased during obesity in mice and human adipose tissues [41]. Gao, et al. found that capsaicin could activate the AMPK-SIRT3 positive-feedback loop to epigenetically inhibit MCU-dependent mitochondrial $\mathrm{Ca}^{2+}$ overload in brown adipocytes, thus maintaining the morphology and function of BAT against whitening stimuli [42].

Notably, different subunit combinations can potentially form functionally distinct complexes with distinct substrate specificities. However, as far as the current study is concerned, no studies in animal models have considered this question. Moreover, there are still many mechanisms through which AMPK affects BAT activity, such as creatine and calcium shuttles which are UCP1-independent thermogenesis pathways.

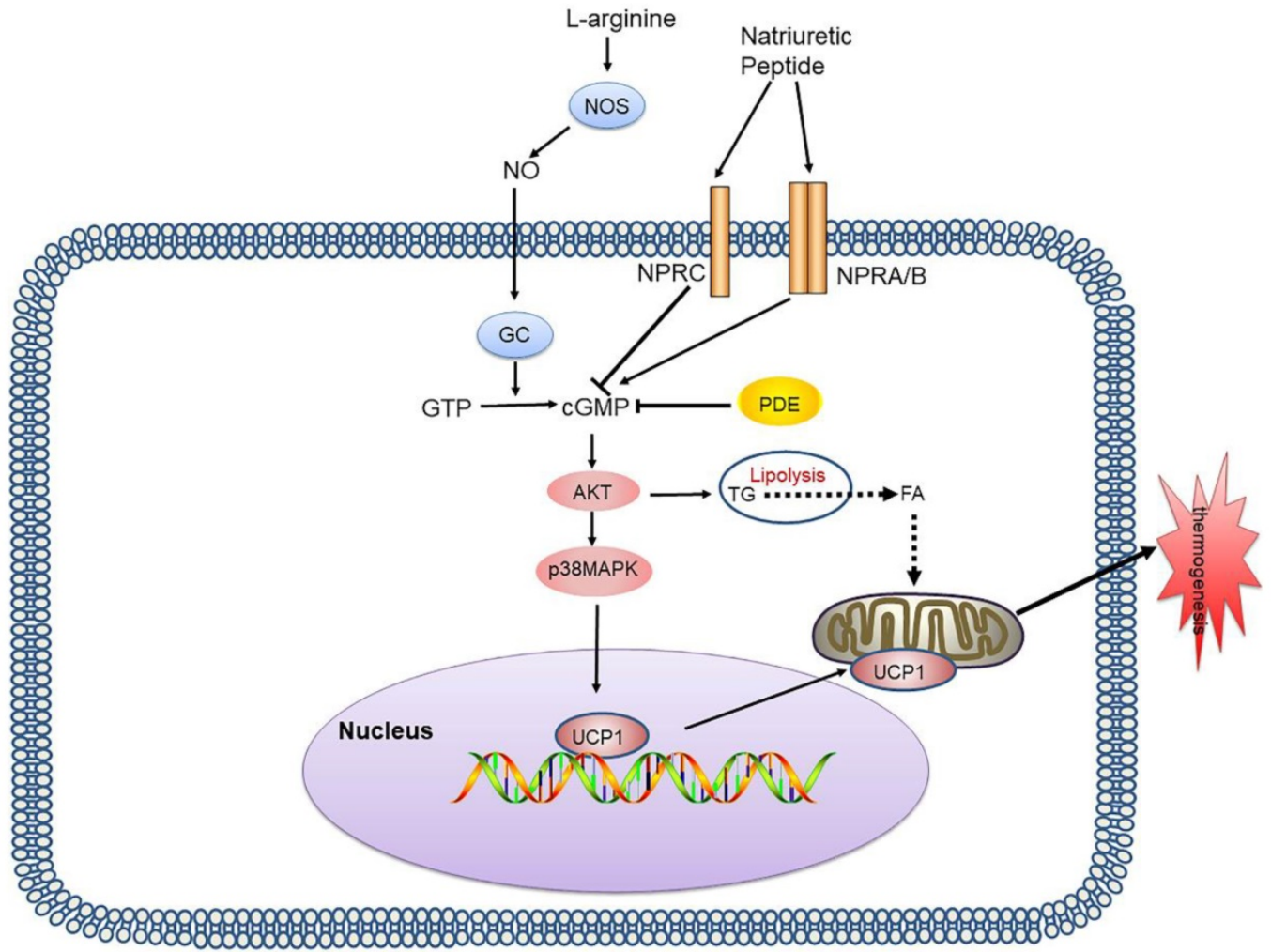

Figure 2. cGMP-AKT signalling pathway and its signalling networks. Nitric oxide synthases mediate endogenous NO production by converting L-arginine into citrulline. NO activates GCs in adipocytes, thereby increasing the intracellular cGMP concentration which results in AKT phosphorylation and activates lipolysis and UCPI expression. NP binds to NPR and induces cGMP production, due to its GC activity. PDE also inhibits cGMP and inhibits thermogenesis. NO: nitric oxide; GCs: guanylyl cyclases; cGMP: cyclic guanosine monophosphate; AKT: protein kinase A; NP: natriuretic peptide; NPR: natriuretic peptide receptor 


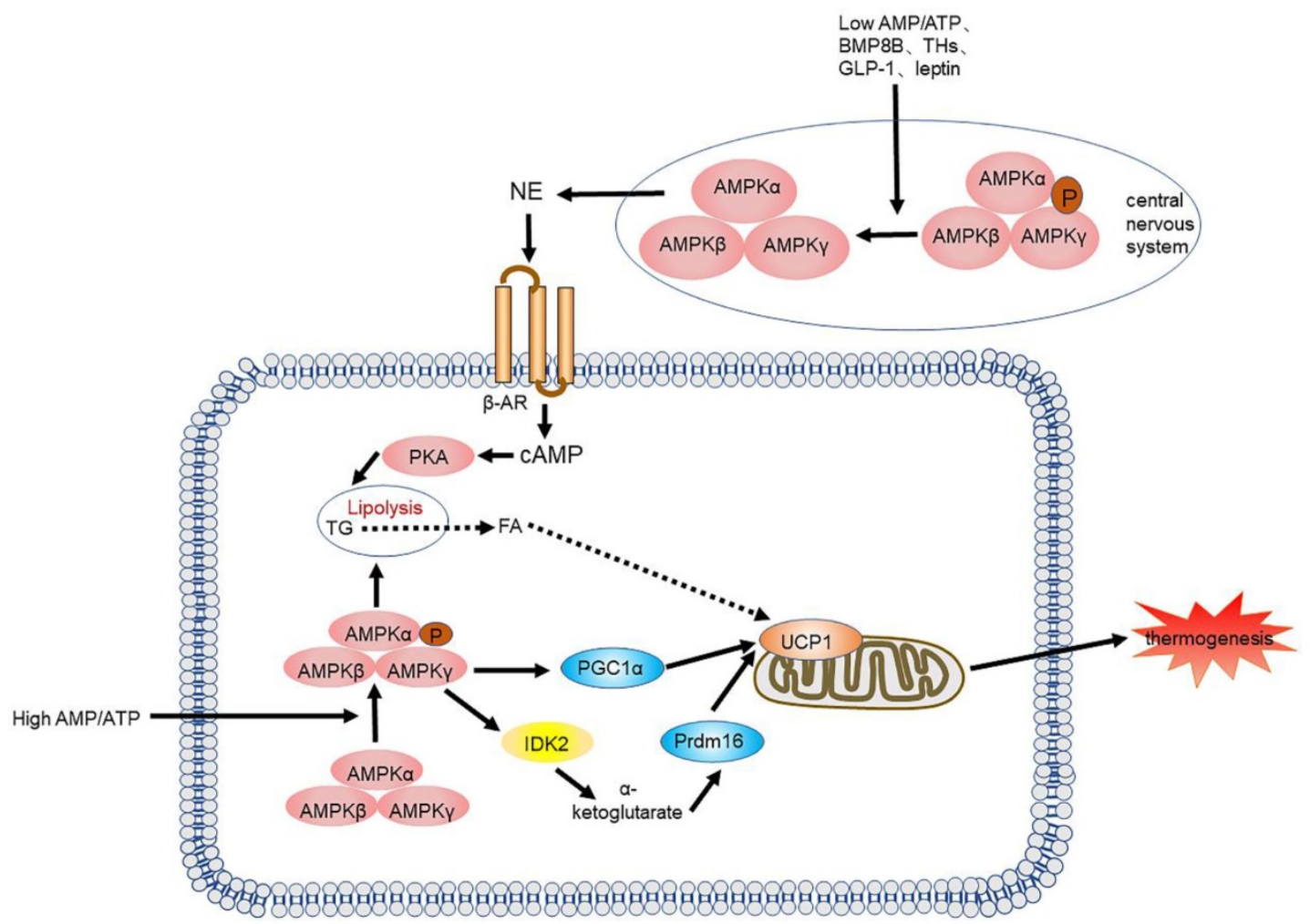

Figure 3. AMPK signalling pathway and its signalling networks. Low AMP/ATP ratios, BMP8B, THs, GLP-1 and leptin inhibit AMPK activity in the hypothalamus, leading to NE release, which leads to an increase in adipogenesis and thermogenesis through the CAMP-PKA signalling pathway. A high AMP/ATP ratio activates AMPK, resulting in increased UCPI transcription and the expression of other thermogenic genes. AMPK also increases the activity of the TCA cycle enzyme IDH2, yielding $\alpha-K G$, which leads to demethylation of Prdm 16 and results in thermogenesis. BMP8B: bone morphogenetic protein 8B; THs: thyroid hormones; GLP-1: glucagon-like peptide-1; AMPK: AMP-activated

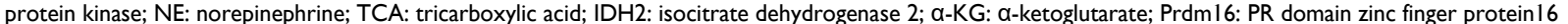

AMPK is also essential in the central nervous system (CNS), especially in the hypothalamus. Recently, increasing evidence has suggested that numerous hormonal factors, such as leptin [43, 44], thyroid hormones [45, 46], and glucagon-like peptide-1(GLP-1) [47-49] control BAT differentiation and thermogenesis by suppressing hypothalamic AMPK activity. Collazo, et al. showed that inhibiting AMPK in the ventromedial nucleus of the hypothalamus can counter high fat diet (HFD)-induced obesity by activating BAT thermogenesis and subsequently energy consumption [50]. Rosalía et al. recently demonstrated that carnitine palmitoyltransferase I(CPT1C) may be a downstream factor of AMPK that regulates hypothalamic thermogenesis. All these studies suggest that we should consider the interplay of these two roles when investigating the functionality of AMPK (Figure 3).

Although in vitro and in vivo results are encouraging, whether the effects of AMPK activation have a similar therapeutic action in humans living in a thermoneutral environment is not clear. In addition, many mechanisms of AMPK in thermogenesis remain to be investigated, such as determining whether AMPK is involved in non-shivering thermogenesis independent of UCP1, including creatine and calcium round-trip. Moreover, clinical use of AMPK in the treatment of obesity is also confronted with many difficulties, such as how to perform site-specific targeting of AMPK in the human hypothalamus.

\section{mTOR signalling pathway}

mTOR is involved in many important metabolic processes including lipogenesis and energy expenditure in BAT [51, 52]. The most critical components of mTORC1 are the regulatory associated proteins of mTOR (Raptor) and the DEP domain-containing mTOR interacting protein (Deptor) and most upstream or downstream stimulation works through these two mTORC1 cores [53]. mTORC2 shares Deptor with mTORC1 but has a unique element: Raptor-independent companion of mTOR (Rictor) [53]. Raptor binding with the mTOR substrate motif is necessary for effective catalytic phosphorylation of mTOR. mTORC1/2 signalling regulates lipolysis, lipogenesis and mitochondrial function, and controls thermogenic gene expression to influence thermogenesis [54]. Furthermore, mTOR also regulates autophagy [55].

The role of mTOR signalling in adipose thermogenesis is still unclear. Raptora ${ }^{\mathrm{P2}-\mathrm{Cre}}$ mice, a type of mice with adipocyte-specific deletion of Raptor, were found to show increased the expression 
of browning and thermogenic genes in WAT, and to have increased energy expenditure [56]. In contrast, RaptorAdipoq-Cre mice, another type of mice with adipocyte-specific deletion of Raptor, also exhibit increased UCP1 expression and browning in WAT, but have no increase in energy expenditure $[57,58]$. The BAT mass and expression of thermogenic genes are decreased in Raptor ${ }^{\text {Adipoq-Cre }}$ mice which suggests that $\mathrm{mTORC} 1$ is required for BAT formation and maintenance [57]. All these studies indicate that the differential effects of mTORC1 on thermogenesis in WAT and BAT may be mediated via a noncell-autonomous mechanism. The underlying mechanism by which mTORC1 functions in WAT and BAT remains enigmatic and needs further study.

Therefore, it is not difficult to understand that mTORC1 can be activated by many regulators, such as growth factors, oxygen, amino acids and certain signalling pathways, such as WNT, Hippo and Notch. The most classic pathway by which mTORC1 participates in lipid metabolism is the binding of insulin-like growth factor and insulin to its receptor, which activates phosphatidylinositol-3-kinase (PI3K)/Akt signalling, inhibits Tsc $1 / 2$, and leads to activation of GTP-RHEB, increasing the activity of mTORC1 against various substrates (including 4E-BP, ULK1, Lipin1, S6K and Grb10). Knockout of the Tsc 1 gene activates mTORC1 signalling to inhibit the expression of UCP1 and thermogenic genes in BAT $[59,60]$. Specific destruction of Grb10 expression in BAT enhances mTORC1 signalling, reduces the core body temperature and cold tolerance of mice, and weakens the expression of thermogenesis genes induced by cold in BAT [61]. Similarly, white adipocytes of $56 \mathrm{~K}^{--}$mice also showed increased UCP1 expression [62]. Recent studies have found that NP-cGMP signalling can also activate mTORC1 through PKG, thereby inducing adipose browning [63]. Many recent studies have found that certain regulatory factors, including SNS, T3, and Mark4, can affect autophagy by regulating mTOR, ultimately regulating thermogenesis [64-66].

In contrast to mTORC1, few studies have investigated the effect of the mTORC2 signalling pathway on BAT thermogenesis. Studies suggest that mTORC2 signalling is stimulated by $\beta$-AR or cold and then activates glucose metabolism and lipid oxidation in BAT, which is associated with thermogenesis [67]. However, mTORC2 stimulates transport of glucose trans porter-1 (GLUT1) to the plasma membrane, increasing glucose uptake, irrespective of the classical insulin-PI3K-Akt pathway [68]. Recently, Su, et al. showed that Rictor deletion in the BAT of mice inhibited lipid synthesis, and facilitated lipid catabolism and thermogenesis by activating the FoxO1 transcription factor, which is related to the mTORC2 substrate SGK, driving sirt6-mediated deacetylation of FoxO1 [69]. Similarly, we cannot determine whether mTORC2 interacts with mTORC1 to influence heat production by BAT. In the future, we must explore more direct and targeted models and methods. Moreover, the crosstalk between mTORC1 and $\mathrm{mTORC} 2$ in thermogenesis is not clear (Figure 4).

\section{TGF- $\beta$ /BMP signalling pathway}

Transforming growth factor- $\beta /$ bone morphogenic protein (TGF- $\beta / B M P$ ) signalling participates in most cellular processes and plays an important role in all metazoans. The TGF- $\beta$ family consists of TGF- $\beta$, BMPs, and activin/inhibin and classical TGF- $\beta$ /BMP signalling has a core that involves TGF- $\beta$ /BMP ligands, signal transducers (Smads) and receptors (type I and II) [70].

Binding of Smad3 to PGC-1 inhibits its transcription, causing TGF- $\beta / \mathrm{BMP}$ signalling to inhibit brown adipocytes differentiation and thermogenesis. Smad $3^{-/}$mice showed enhanced insulin sensitivity and reduced obesity, insulin resistance, and hepatic steatosis [71]. The absence of $T \beta R I$ promotes the formation of beige fat and reduces the harmful effects of HFD feeding [72]. BMP4 promotes differentiation of human adipose stem cells into beige adipocytes, but decreases the expression of UCP1 and PGC-1a in BAT [73]. Recently, BMP4 was found to have no effect on established obesity phenotypes, suggesting that BMP4 has a greater effect on brown adipocyte differentiation [74]. BMP8B controls energy balance and is dependent on the degree of AMPK activation in the hypothalamus [75]. In addition, other members of the BMP family are also involved in metabolism. For example, BMP7 and BMP8a can promote BAT thermogenesis, but the thermogenesis induced by BMP8a only appears in female mice, which may be because BMP8a-induced thermogenesis is mediated by oestrogen; hypothalamic BMP9 inhibits glucose production through a central pathway; Noggin, the extracellular inhibitor of BMP, was found to promote WAT browning and BAT thermogenesis $[73,76]$.

How the balance of anti-adipogenic and pro-adipogenic TGF $\beta$ family proteins controls adipose progenitor differentiation by activating receptors and downstream factors, under different energy conditions is not clear. Further studies addressing the significance of TGF $\beta$ members in lipid biology and how their signalling components change would provide strong evidence supporting their potential role in obesity treatment (Figure 5). 


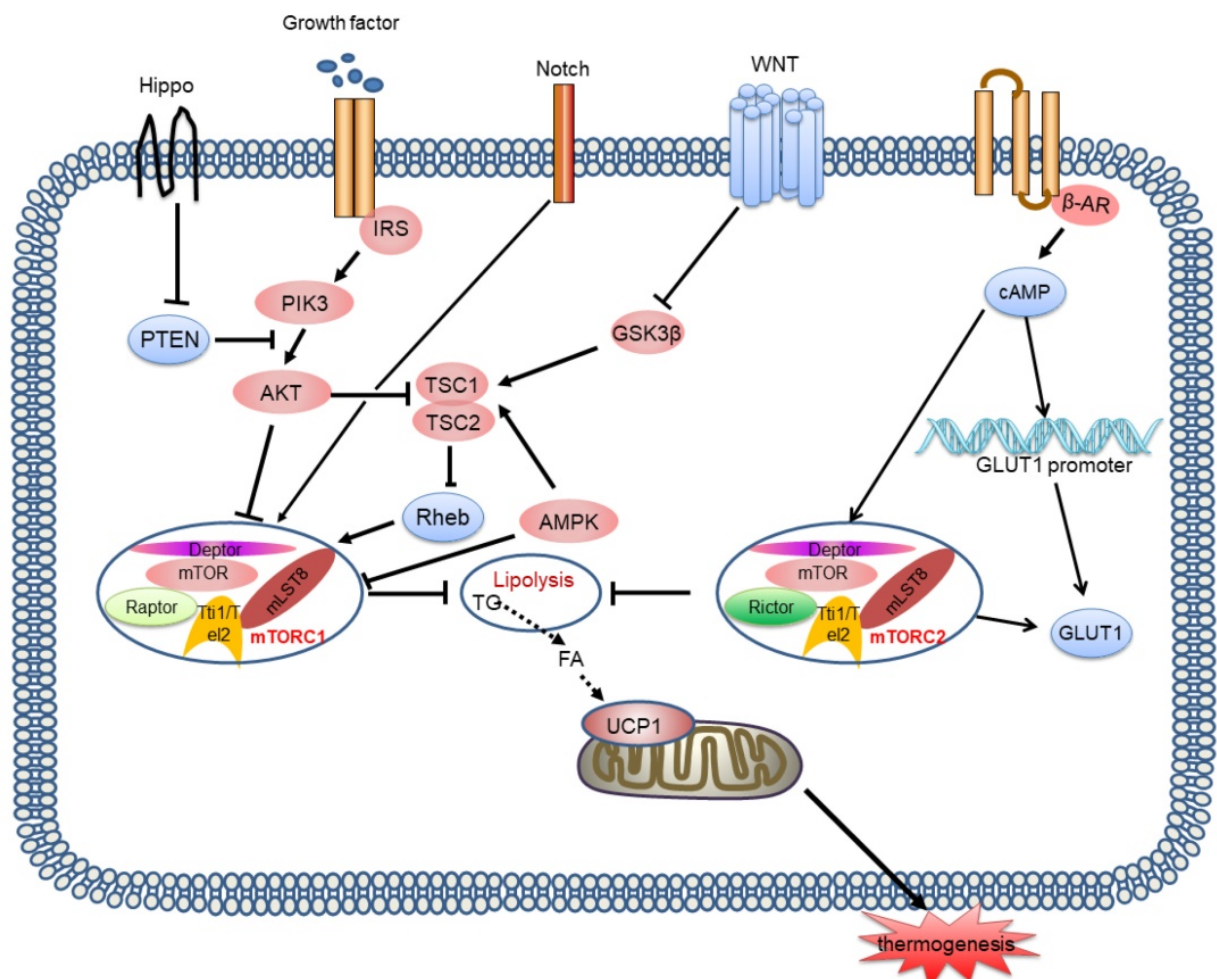

Figure 4. $m$ TORC1 and $m$ TORC2 signalling pathways and their signalling networks. The $\mathrm{mTORC1}$ and $\mathrm{mTORC2}$ signalling pathways are involved in thermogenesis by inhibiting lipolysis and regulating thermogenic gene expression. Growth factors activates the PI3K-AKT-TSC2-mTORCI pathway. Wht signalling inhibits the activation of GSK3 3 , which phosphorylates TSC2, resulting in mTORC1 stimulation. Notch signalling also affects mTOR activity. AMPK phosphorylates TSC2 resulting in inhibition of $m T O R C 1$ activity. Hippo activates $m T O R C 1$ signalling through PTEN suppression. $m T O R C 2$ is also involved in controlling glucose homeostasis. $m$ TORC2 is stimulated by $\beta$-AR and then activates glucose metabolism and lipid oxidation, which is associated with thermogenesis. mTORC2 stimulates GLUTI transport to the plasma membrane and increases glucose uptake. mTOR: mammalian target of rapamycin; PI3K: phosphatidylinositol-3-kinase; GSK3ß: glycogen synthase kinase 3ß; TSC2: tuberous sclerosis complex 2; PTEN: phosphatase and tensin homologue; GLUT1: glucose trans porter-1

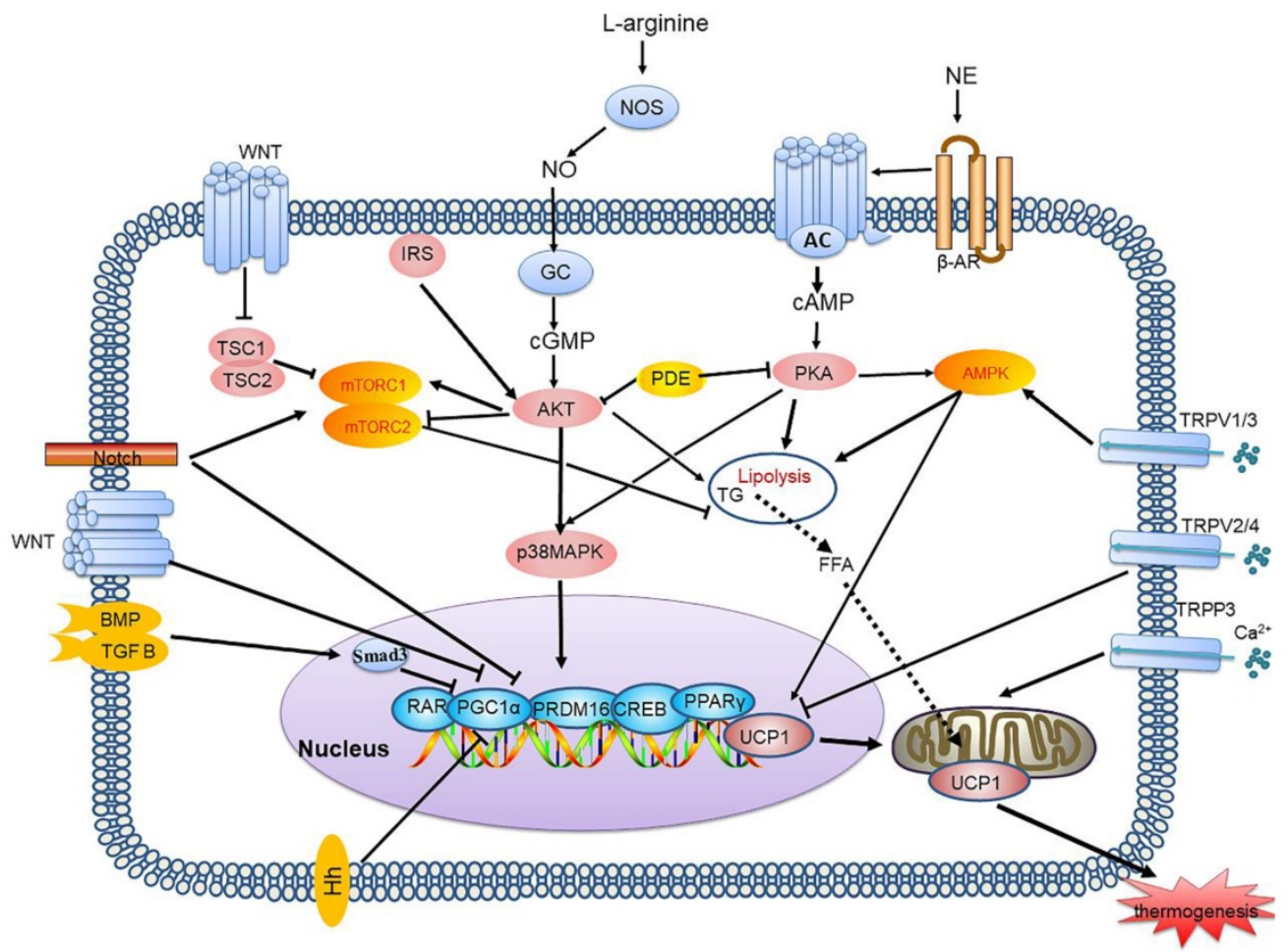

Figure 5. Thermogenesis signalling pathways network. Each signalling pathway plays an important role in adipocyte thermogenesis. Binding of Smad3 to PGC-1 inhibits its transcription, causing TGF- $\beta / B M P$ signalling to inhibit brown adipocyte differentiation and thermogenesis. TRP channels transport Ca ${ }^{2+}$ and can be regarded as managers of intracellular $\mathrm{Ca}^{2+}$ levels, TRPV1/3 activate thermogenesis and TRPV2/4 inhibit thermogenesis. TRPP3 can enhance mitochondrial function. Notch signalling can regulate thermogenesis by influencing mTOR activity and directly inhibiting thermogenic gene expression. Hh inhibits WAT browning by downregulating thermogenic gene expression. The Wnt/ $\beta$-catenin pathway inhibits adipogenesis and thermogenic programs by inhibiting transcription factors. PGC-1: PPARY coactivator-1 $\alpha$; TGF- $\beta / B M P$ : transforming growth factor-B/bone morphogenic protein; TRP: transient receptor potential; Hh: Hedgehog; WAT: white adipose tissue 


\section{TRP channels}

TRP channels reside extensively on the membranes of various cells [77]. TRP channels transport $\mathrm{Ca}^{2+}$ and can be regarded as managers of intracellular $\mathrm{Ca}^{2+}$ levels. Channels mediate $\mathrm{Ca}^{2+}$ influx in different ways, influencing several $\mathrm{Ca}^{2+}$ dependent signalling pathways and thereby affecting cell metabolism, differentiation, and gene expression [77, 78].

TRPV1, the first TPR channel to be identified in adipose tissue, is activated by medium temperature $\left(\geq 43^{\circ} \mathrm{C}\right)$, and by various other stimuli such as low $\mathrm{pH}$, capsaicin, and inflammatory factors [77]. Capsaicin, a TRPV1 activator, promotes the expression of thermogenic genes in BAT by stimulating $\mathrm{Ca}^{2+}$ influx [79]. However, studies have also found that TRPV1 in the nucleus of the solitary tract inhibits BAT thermogenesis in HFD rats [80]. All these studies indicate that the effects of TRPV1 on obesity are complex. TRPV1 not only exists in adipose tissue, but also influences the CNS and gastrointestinal tract, which suggests that TRP channels in different tissues may have different effects and that the gut-brain axis may be an approach for obesity treatment.

TRPV3 expression was found to be significantly decreased in BAT and WAT, while TRPV2 and TRPV4 expression was increased, which shows that TRPV3 is similar to TRPV1 and that TRPV2/4 are opposite to TRPV1[81].

TRPV2 is a nonselective calcium-permeable cation channel that is activated by toxins and high temperatures (above $52^{\circ} \mathrm{C}$ ) [82]. The expression of thermogenic genes was decreased in TRPV2 deficient mice and TRPV2 mRNA was detected in brown fat cells in vitro [83]. However, studies also found that TRPV2 agonists inhibited the differentiation of brown adipocytes [84]. This opposite effect on obesity may be related to $\mathrm{Ca}^{2+}$ influx: excess $\mathrm{Ca}^{2+}$ influx has a negative effect on BAT differentiation but is good for maintaining normal BAT thermogenesis.

The TRPM8 channel is a unique TRP channel that is induced by low temperature (below $26-28^{\circ} \mathrm{C}$ ) stimulation [85]. Menthol, a TRPM8 agonist, was found to activate TRPM8, resulting in PKA activation, UCP1 upregulation and increased thermogenesis [86]. Meanwhile, inhibition of mitochondrial uncoupled respiration by streptomycin was achieved by inhibiting TRPM8-mediated calcium transport [87]. In addition, TRPM8 was found to be involved in BAT clock regulation similar to TRPV1 and when TRPM8 was deficient, BAT clock regulation was disordered, resulting in a decrease in UCP1 expression [88].

Other TRP channels also play a role in thermogenesis (Figure 5). TRPC1 is a possible target of PPARY that promotes BAT thermogenesis [89]. TRPP3 enhances mitochondrial function and promotes BAT differentiation [87]. TRP channels respond to multiple environmental stimuli, such as temperature, food ingredients and poisoning, which indicates that the mechanism by which TRP channels are regulated is intricate. TRP channels have different effects in different tissues and even in different stages of adipose tissue differentiation, and elucidating the detailed mechanisms that regulate TRP channels might be difficult. Meanwhile, natural product ingredients regulate the function of TRP channels, and further investigation of the potential principle underlying their roles in obesity is urgent.

\section{Wnt/NF-kB/Notch/Hh signalling pathway}

The Notch signalling pathway is a highly conserved pathway that is important for many cellular processes including survival, proliferation and differentiation [90]. Previous studies have suggested that the Notch pathway inhibits the browning of WAT $[90,91]$. Bi et al. found that Notch signalling inhibits the transcription of thermogenic related genes, including Prdm16 and Ppargcla in WAT [92]. Huang et al. found that the reduction in subcutaneous adipose tissue expansion in pigs is mediated by inhibition of Notch signalling [93]. However, a recent study suggested that Notch signalling promotes PKA activation and thermogenic gene expression in BAT, which is the opposite of the effects reported in previous studies in WAT [94]. In addition, the researchers showed that Ras homolog enriched in the brain (Rheb) is a GTP-binding protein that promotes thermogenesis in BAT via activation of the Notch signalling pathway. How to explain the opposite mechanisms has not been determined, and further mechanisms have been lacking, including how Notch signalling regulates browning, and whether it controls adipocyte precursor differentiation or mature cell interconversion. We hypothesize that Notch signalling may be regulated by other regulators or pathways, or that there are distinct Notch receptors in WAT and BAT that have not yet been found. This should be explored in more depth. In short, Notch signalling plays a role in BAT thermogenesis or in the browning of WAT (Figure 5).

Previous studies have shown that the $\mathrm{Hh}$ pathway is highly conserved in fat and is expressed in both fly and mouse fat. The Hh pathway blocks the early steps of adipogenesis, downregulates the adipogenic transcription factor PPARY and induces the expression of osteogenic transcription factors [95]. In this study, the researchers found that the $\mathrm{Hh}$ signalling pathway blocks differentiation of brown preadipocytes and promotes differentiation of 
preadipocytes towards skeletal muscle, thus inhibiting BAT formation in the body [96]. Leptin also induces WAT browning by suppressing the $\mathrm{Hh}$ signalling pathway [97]. However, in mature osteoblasts, upregulated Hh signalling was found to activate the endocrine action of bone-derived PTHrP, which causes continuous acceleration of bone remodelling and WAT browning for increased energy consumption [98]. Although the effect is different, studies suggest that $\mathrm{Hh}$ signalling is involved in thermogenesis through WAT browning but not in the BAT thermogenic program (Figure 5).

The classical Wnt/ $\beta$-catenin pathway inhibits adipogenesis and thermogenic programs by inhibiting transcription factors including PPARY, CEBPa and PGC1a [99-101]. The Wnt/ $\beta$-catenin pathway is a major axis, and many signalling pathways are connected through the Wnt/ $\beta$-catenin pathway by regulating the expression of specific factors in the Wnt/ $\beta$-catenin pathway. For example, lysine-specific demethylase 1 (LSD1) promotes brown fat formation via demethylation of $\mathrm{H} 3 \mathrm{~K} 4$ in the promoter region of the Wnt signalling module, thereby inhibiting the Wnt pathway [102]. STAT3 induces differentiation of primary brown preadipocytes during the induction phase. Loss of STAT3 leads to upregulation of the Wnt ligand, and inhibition of the Wnt/ $\beta$-catenin pathway can restore differentiation [103]. Overall, the Wnt signalling pathway plays a vital role in thermogenesis and can be a therapeutic target for obesity and other associated metabolic complications (Figure 5).

The NF- $\mathrm{kB}$ signalling pathway is responsible for induction of inflammatory genes and innate immunity, including a family of transcription factors [104]. Zhang et al. found that dysregulation of NF-KB was mediated by SOCS3 in the hypothalamus [105], suggesting that NF-KB signalling is involved in energy balance. NF- $\mathrm{KB}$ signalling was shown to involve activation of oxidative phosphorylation by upregulating mitochondrial synthesis to distribute energy [106]. Immediate early response gene X-1 (IEX-1) is a downstream target of NF-кB. IEX-1 inhibits WAT browning and activates thermogenic programs in WAT by promoting selective activation of fat macrophages [107]. Homeobox a5 (Hoxa5), a developmental transcription factor, promotes WAT browning by inhibiting the tenascin $\mathrm{C}$ (TNC)-mediated Toll-like receptor (TLR) 4/NF-kB pathway and activating the BMP4/Smad1 pathway [108]. Overall, the NF-kB signalling pathway may be a target for thermogenesis and associated metabolic diseases. This also suggests that the link between inflammation and thermogenesis is a worthwhile direction for obesity treatment (Figure 5).

\section{Potential therapeutic applications in BAT}

Adipose tissue is indispensable for total energy homeostasis, and adipose tissue dysfunction leads to metabolic diseases. Because of the ability of brown or beige adipocytes to expend energy, adipose tissue could be useful in treating obesity and other metabolic-related diseases. BAT and beige fat are involved in thermogenesis, and BAT and beige fat cells could potentially be activated as a therapeutic approach via several signalling pathways or certain regulatory factors. Nevertheless, recruitment and activation of human brown or beige adipocytes remain a challenge.

The classical method is cold exposure. Acute cold exposure $\left(10^{\circ} \mathrm{C}, 4 \mathrm{~h}\right)$ induces UCP1-mediated thermogenesis-dependent glucose utilization by affecting amino acid metabolism in BAT [109]. Chronic cold exposure $\left(6^{\circ} \mathrm{C}, 10\right.$ days $)$ has also been shown to activate glucose oxidation in BAT and WAT browning [110]. Previous studies have found that intermittent cold exposure increases BAT thermogenesis [111]. However, this time-consuming technique is uncomfortable and would be undesirable due to the increased cardiovascular risks of atherosclerotic plaque growth or instability [112]. Moreover, further research is needed to determine whether these benefits will be sustained over the long term. After all, there are many ways in which the body can sense stimuli, control physiological responses, and ultimately adapt to the environment.

Pharmacotherapy to activate thermogenesis is an attractive choice. $\beta 3$-AR agonists have been investigated for obesity treatment. The most common $\beta 3$-AR agonists used in experiments to stimulate thermogenesis in brown adipocytes are CL316243, BRL-37344, and L-796568. Mirabegron, which is a 33 -AR agonist applied for bladder hyperactivity therapy, was shown to activate BAT in rats and humans [113]. However, Sui, et al. showed that the clinical dose of mirabegron induces BAT excitation and WAT browning and thereby leads to atherosclerotic plaque development [114]. One study reported that RepSox, an inhibitor of TGF $\beta-R I$, induces fat generation in mouse embryonic fibroblasts (MEFs) grown in fibroblast culture medium [115]. Troglitazone, a PPARY activator, promotes browning of WAT by activating TRPV1 and causing deacetylation of PPARY [116]. Rapamycin inhibits mTOR signalling. Recent studies have shown that short-term rapamycin treatment can lead to a variety of metabolic syndromes, such as hyperlipidaemia and insulin resistance, while prolonged treatment can lead to beneficial metabolic changes, including reduced obesity, increased insulin sensitivity, and improved blood lipids [117]. These results suggest that the 
duration of rapamycin treatment might have different effects on metabolism, and that rapamycin has limitations in application for obesity disease. Nitrate is a substrate for NO production. Fatemeh, et al. showed that long-term nitrate administration has favourable effects on adiposity by increasing BAT and decreasing WAT in normal female rats [118]. Some of these drugs have poor targeting, some have poor efficacy, and some have a variety of side effects. All these factors make them unsuitable for use in humans.

Currently, natural products targeting thermogenesis for treatment of obesity in the clinic have attracted public attention. How to influence thermogenesis through various signalling pathways is increasingly being studied.

In regard to the natural products that induce BAT thermogenesis, capsaicin must be the first compound people considered. Capsaicin, the most commonly occurring capsaicinoid, is a representative agonist of TRP [119]. Classical research has demonstrated that oral administration of capsaicin activates TRP channels, especially TRPV1, in sensory neurons of the gastrointestinal tract, provokes thermogenesis via a $\beta$-AR-mediated pathway in BAT (TRP-SNS-UCP1 axis) and triggers browning of WAT [120, 121]. Recent studies have also found that capsaicin can activate intracellular $\mathrm{Ca}^{2+}$ rise via TRPV1 channels, promote CaMKII/AMPK phosphorylation, and then activate SIRT-1, which facilitates interaction of PPARY and PRDM-16 to enhance WAT browning and BAT thermogenesis [42, $79,122]$. In addition to capsaicin, other natural product ingredients have agonistic activity towards TRPV1, including royal jelly (RJ) [123, 124], and sulphur-containing compounds in durian [125]. In addition to TRPV1, they also activate TRPA1, which is a member of the TRP family. Cinnamaldehyde (CA) [126], menthol [127], and allyl isothiocyanate [128], among others, have agonistic activity towards TRPM8 and TRPA1, and thus may also have the potential to activate BAT thermogenesis. An introduction to these natural product ingredients can be found in Table 1, but will not be detailed here.

Table 1. Summary of natural products reported in recent years and the mechanisms of their active ingredients that promote non-shivering thermogenesis via signalling pathways[129].

\begin{tabular}{|c|c|c|c|c|c|}
\hline Signalling pathways & Source & $\begin{array}{l}\text { Dietary } \\
\text { component }\end{array}$ & Mechanism of action & Models & Ref \\
\hline cAMP-PKA & Korean ginseng & Ginsenosides (GEF) & $\begin{array}{l}\text { inhibit fat accumulation and } \\
\text { increases energy expenditure in } \\
\text { white adipocytes through PKA } \\
\text { activation }\end{array}$ & $\begin{array}{l}\text { Mouse 3T3-L1 pre-adipocytes, } \\
\text { Mouse primary subcutaneous } \\
\text { adipocytes (SAT) }\end{array}$ & [130] \\
\hline cAMP-PKA & $\begin{array}{l}\text { Bitter melon seed } \\
\text { oil (BMSO) }\end{array}$ & $\begin{array}{l}\text { Cis-9, trans- } 11 \text {, trans- } 13 \text { isomer of } \\
\text { conjugated linolenic acid }\end{array}$ & $\begin{array}{l}\text { activate PKA and program cell death } \\
\text { in WAT }\end{array}$ & $\begin{array}{l}\text { Male C57BL/ } 6 \mathrm{JN} \text { mice }(7 \text { weeks } \\
\text { old) }\end{array}$ & [131] \\
\hline cAMP-PKA & $\begin{array}{l}\text { Black mustard } \\
\text { seeds, wine, and } \\
\text { vinegar }\end{array}$ & Sinapic acid (SA) & $\begin{array}{l}\text { stimulate mitochondrial biogenesis, } \\
\text { WAT browning and lipolysis via the } \\
\text { p38 MAPK-CREB pathway; activate } \\
\text { thermogenesis via PKA-CREB } \\
\text { signalling }\end{array}$ & 3T3-L1 pre-adipocytes; BAT cells & $\begin{array}{l}{[132,} \\
133]\end{array}$ \\
\hline cAMP-PKA, AMPK & Turmeric & Curcumin & $\begin{array}{l}\text { induce browning via an } \\
\text { AMPK-mediated pathway; lead to } \\
\text { lipid metabolism and energy } \\
\text { homeostasis by increasing } \\
\text { cAMP-PKA/CREB signalling } \\
\text { pathways; promote adipogenic } \\
\text { differentiation of preadipocytes and } \\
\text { mitochondrial oxygen consumption }\end{array}$ & $\begin{array}{l}\text { 3T3-L1 preadipocytes, Male } \\
\text { C57BL/ } 6 \text { J mice ( } 6 \text { weeks old), } \\
\text { Primary adipocytes, Mouse brown } \\
\text { adipocytes, Male } d b / d b \text { C57BL/ } 6 \\
\text { mice }\end{array}$ & $\begin{array}{l}{[134-136]} \\
{[137]}\end{array}$ \\
\hline $\begin{array}{l}\text { PKA-p38MAPK-CREB, } \\
\text { AMPK }\end{array}$ & Mangifera indica & Mangiferin (MF) & $\begin{array}{l}\text { promote thermogenesis in brown } \\
\text { preadipocytes via activation of } \\
\text { AMPK and PKA-p38 MAPK-CREB } \\
\text { Signalling pathways }\end{array}$ & $\begin{array}{l}\text { C3H10T1/2 MSCs, Brown } \\
\text { preadipocytes }\end{array}$ & $\begin{array}{l}{[138,} \\
139]\end{array}$ \\
\hline cAMP-PKA, AMPK & Fruits of hazel trees & Filbertone $\left(\mathrm{C}_{8} \mathrm{H}_{14} \mathrm{O}\right)$ & $\begin{array}{l}\text { induce cAMP and then activate PKA, } \\
\text { thus inducing phosphorylation of } \\
\text { AMPK and CREB and thereby } \\
\text { inhibiting adipogenesis, resulting in } \\
\text { increased thermogenesis }\end{array}$ & $\begin{array}{l}\text { Male C57BL/ } 6 \mathrm{~N} \text { mice }(5 \text { weeks } \\
\text { old), 3T3-L1 pre-adipocytes }\end{array}$ & [140] \\
\hline PKA-p38 MAPK & Cinnamon & Cinnamaldehyde (CA) & $\begin{array}{l}\text { activate PKA Signalling, increase } \\
\text { expression of thermogenic genes and } \\
\text { induce phosphorylation of HSL and } \\
\text { PLIN1 }\end{array}$ & $\begin{array}{l}\text { Primary preadipocytes; Human } \\
\text { adipose-derived stem cells } \\
\text { (hASCs) }\end{array}$ & [126] \\
\hline$\beta 3$-AR-MAPK, AMPK & Many plants & Quercetin & $\begin{array}{l}\text { promote UCP1 expression through } \\
\text { the } \beta 3-\mathrm{AR} \text { and AMPK pathways }\end{array}$ & $\begin{array}{l}\text { Male C57BL/ } 6 \text { mice ( } 4 \text { weeks old), } \\
\text { Primary brown preadipocytes }\end{array}$ & [141] \\
\hline PI3K-Akt & Ishige okamurae & Ishige okamurae extract (IOE) & $\begin{array}{l}\text { activate the PI3K/Akt pathway and } \\
\text { increase the expression of } \\
\text { pro-thermogenic genes }\end{array}$ & $\begin{array}{l}\text { Male } d b / d b \text { and lean } d b /+ \text { mice } \\
\text { (5 weeks old) }\end{array}$ & [142] \\
\hline$\beta 3$-AR-PKA, AMPK & $\begin{array}{l}\text { various plants of } \\
\text { more than } 20 \\
\text { species, including } \\
\text { fennel, anise, and } \\
\text { star anise, and has }\end{array}$ & $\begin{array}{l}\text { Trans-anethole } \\
\text { (trans-1-methyoxy-4-propenyl-benzene) }\end{array}$ & $\begin{array}{l}\text { induce browning through activation } \\
\text { of the } \beta 3-A R \text { and AMPK-SIRT1 } \\
\text { pathways }\end{array}$ & $\begin{array}{l}\text { 3T3-L1 preadipocytes, Male } \\
\text { C57BL/ } 6 \text { mice ( } 5 \text { weeks old) }\end{array}$ & [143] \\
\hline
\end{tabular}




\begin{tabular}{|c|c|c|c|c|c|}
\hline Signalling pathways & Source & $\begin{array}{l}\text { Dietary } \\
\text { component }\end{array}$ & Mechanism of action & Models & Ref \\
\hline & $\begin{array}{l}\text { been used for } \\
\text { culinary purposes } \\
\text { for centuries }\end{array}$ & & & & \\
\hline PKA, AMPK & $\begin{array}{l}\text { Magnolia officinalis } \\
\text { (magnolia bark) }\end{array}$ & Magnolol & $\begin{array}{l}\text { prevent oxidative stress and promote } \\
\text { WAT browning by activating } \\
\text { PPARY-, pAMPK-, and } \\
\text { PKA-mediated pathways }\end{array}$ & 3T3-L1 preadipocytes & [144] \\
\hline PKA, AMPK & $\begin{array}{l}\text { Numerous aromatic } \\
\text { plants such as } \\
\text { thyme species }\end{array}$ & Thymol (5-methyl-2-isopropylphenol) & $\begin{array}{l}\text { induce WAT browning by activating } \\
\beta 3 \text {-AR-PKA-p38MAPK; alleviate } \\
\text { lipogenesis by activating the AMPK } \\
\text { pathway }\end{array}$ & 3T3-L1 preadipocytes & [145] \\
\hline AMPK, PI3K/AKT & Paeonia lactiflora & Albiflorin (AF) & $\begin{array}{l}\text { induce brown adipogenesis by } \\
\text { activating the AMPK and PI } 3 \mathrm{~K} / \mathrm{AKT} \\
\text { Signalling pathway }\end{array}$ & $\begin{array}{l}\text { human adipose tissue-derived } \\
\text { mesenchymal stem cells } \\
\text { (HAMSCs), Male C57BL/6J mice } \\
\text { (4 weeks old), Brown } \\
\text { preadipocytes }\end{array}$ & [146] \\
\hline $\begin{array}{l}\text { PKA, AMPK-p38 } \\
\text { MAPK }\end{array}$ & $\begin{array}{l}\text { Various plants, } \\
\text { such as dill, vanilla, } \\
\text { violet flowers, and } \\
\text { black pepper }\end{array}$ & Piperonal $\left(\mathrm{C}_{8} \mathrm{H}_{6} \mathrm{O}_{3}\right)$ & $\begin{array}{l}\text { increase PKA Signalling in WAT, } \\
\text { regulate glucose uptake by inducing } \\
\text { the lactate-AMPK-p38 MAPK } \\
\text { pathway; cause mitochondrial } \\
\text { respiration regulation via UCP1 } \\
\text { induction }\end{array}$ & $\begin{array}{l}\text { C57BL/6N mice, mouse embryo } \\
\text { 3T3-L1 fibroblast cells, mouse } \\
\text { C2C12 myoblasts, rat L6 } \\
\text { myoblasts, 3T3-L1 preadipocytes }\end{array}$ & $\begin{array}{l}{[147,} \\
148]\end{array}$ \\
\hline AMPK & $\begin{array}{l}\text { Panax notoginseng } \\
\text { saponins (PNS) }\end{array}$ & $\begin{array}{l}\text { Ginsenosides Rb1, Rd, Re, Rf and Rg1 } \\
\text { and notoginsenoside R1 }\end{array}$ & $\begin{array}{l}\text { increase BAT thermogenesis and } \\
\text { beige adipocyte reconstruction by } \\
\text { activating the leptin-AMPK/STAT3 } \\
\text { Signalling pathway }\end{array}$ & $\begin{array}{l}\text { Male C57BL/ } 6 \mathrm{~J} \text { mice }(4 \text { weeks } \\
\text { old), } d b / d b \text { and } o b / o b \text { mice }\end{array}$ & [149] \\
\hline AMPK & Flaxseed & Secoisolariciresinol diglucoside (SDG) & $\begin{array}{l}\text { increase AMPK activation pathway } \\
\text { and thus activate thermogenesis and } \\
\text { stimulate mitochondrial } \\
\text { biogenesis/activation/fission }\end{array}$ & $\begin{array}{l}\text { Male } d b / d b \text { mice ( } 5 \text { weeks old), } \\
\text { Male C57BL/ } 6 \mathrm{~J} \text { mice }(4 \text { weeks } \\
\text { old), Brown adipocytes, Beige } \\
\text { adipocytes, 3T3-L1 adipocytes, }\end{array}$ & [150] \\
\hline AMPK & $\begin{array}{l}\text { Citrus } \\
\text { aurantiumLinné } \\
\text { (CA) }\end{array}$ & - & $\begin{array}{l}\text { induce adipogenesis and } \\
\text { thermogenesis through AMPK } \\
\text { activation }\end{array}$ & $\begin{array}{l}\text { Male C57BL/6 J mice ( } 4 \text { weeks } \\
\text { old), 3T3-L1 preadipocytes, Brown } \\
\text { adipocytes }\end{array}$ & [151] \\
\hline АMPK, NF-КВ, MAPK & $\begin{array}{l}\text { Fruits and } \\
\text { vegetables }\end{array}$ & Apigenin (AP) & $\begin{array}{l}\text { enhance thermogenesis and } \\
\text { browning via AMPK activation; } \\
\text { reduce adipose tissue metabolic } \\
\text { inflammation (NF-KB, MAPK) }\end{array}$ & Male C57BL/ 6 mice (3 weeks old) & [152] \\
\hline AMPK-PGC1a & $\begin{array}{l}\text { Ginger rhizomes } \\
\text { (Zingiber officinale } \\
\text { Rosco) }\end{array}$ & Ginger extract (GE) & $\begin{array}{l}\text { stimulate browning via the } \\
\text { SIRT1/AMPK/PGC-1a pathway }\end{array}$ & Male C57BL/ 6 J mice (5 weeks old) & [153] \\
\hline AMPK & Rhizoma Coptidis & Berberine (BBR) & $\begin{array}{l}\text { promote brown adipocyte } \\
\text { differentiation and BAT } \\
\text { thermogenesis through the } \\
\text { AMPK-PRDM16 axis; stimulate } \\
\text { UCP1 transcription through AMPK } \\
\text { activation }\end{array}$ & $\begin{array}{l}\text { Male C57BL/6J mice ( } 6 \text { weeks } \\
\text { old), Adipose-specific AMPKa1/a2 } \\
\text { KO mice (AKO), Male } d b / d b \text { mice, } \\
\text { Brown preadipocytes, Primary } \\
\text { stromal vascular (SVF) cells, } \\
\text { C3H10T1/ } 2 \text { cells }\end{array}$ & $\begin{array}{l}{[154,} \\
155]\end{array}$ \\
\hline AMPK-PGC1a & Soy & Genistein & $\begin{array}{l}\text { increase UCP1 expression and that of } \\
\text { some biomarkers of browning via } \\
\text { AMPK pathway activation }\end{array}$ & $\begin{array}{l}\text { Male C57BL/ } 6 \text { mice }(8 \text { weeks old), } \\
\text { 3T3-L1 preadipocytes }\end{array}$ & [156] \\
\hline AMPK & Humulus japonicus & $\begin{array}{l}\text { Aqueous extract of Humulus japonicus } \\
(\mathrm{AH})\end{array}$ & $\begin{array}{l}\text { stimulate browning and } \beta \text {-oxidation } \\
\text { and attenuate hydrogen } \\
\text { peroxide-induced oxidative stress } \\
\text { via AMPK and PPARס-mediated } \\
\text { pathways }\end{array}$ & 3T3-L1 preadipocytes & [157] \\
\hline AMPK & $\begin{array}{l}\text { Outer bark of a } \\
\text { variety of tree } \\
\text { species }\end{array}$ & Betulinic acid (BA) & $\begin{array}{l}\text { facilitate energy expenditure, lipid } \\
\text { oxidation and thermogenesis by } \\
\text { activating the AMPK pathway }\end{array}$ & $\begin{array}{l}\text { 3T3-L1 mouse embryo fibroblasts, } \\
\text { Brown adipocytes, Male C57BL/ } 6 \\
\text { mice ( } 6 \text { weeks old) }\end{array}$ & [158] \\
\hline AMPK & Fungus & Cordycepin (Cpn) & $\begin{array}{l}\text { activate UCP1 expression through } \\
\text { AMPK activation }\end{array}$ & $\begin{array}{l}\text { Male C57BL/ } 6 \text { mice, 3T3-L1 } \\
\text { preadipocytes }\end{array}$ & [159] \\
\hline AMPK & $\begin{array}{l}\text { Platycodi Radix } \\
\text { (root of Platycodon } \\
\text { grandiflorum) }\end{array}$ & Platycodin D (PD) & $\begin{array}{l}\text { decrease adipogenic markers } \\
\text { including PPARY and CEBPa via } \\
\text { AMPK pathway activation and } \\
\text { increase thermogenic factors such as } \\
\text { UCP1 and PGC1a }\end{array}$ & $\begin{array}{l}\text { Male } d b / d b \text { mice and age-matched } \\
\text { WT mice ( } 5 \text { weeks old), 3T3-L1 } \\
\text { mouse embryo fibroblasts, Brown } \\
\text { adipocytes, hAMSCs }\end{array}$ & [160] \\
\hline AMPK & Humulus lupus & Xanthohumol (XN) & $\begin{array}{l}\text { activate AMPK resulting in beiging } \\
\text { of } 3 \mathrm{~T} 3-\mathrm{L} 1 \text { adipocytes, enhance } \\
\text { lipolysis and inhibit adipogenesis }\end{array}$ & $\begin{array}{l}\text { 3T3-L1 mouse embryo } \\
\text { preadipocyte cell, Primary human } \\
\text { subcutaneous preadipocytes }\end{array}$ & [161] \\
\hline AMPK & Raspberry (RAS) & polyphenols & $\begin{array}{l}\text { stimulate the expression of } \\
\text { thermogenic genes and beige } \\
\text { adipocyte formation through the } \\
\text { AMPK pathway }\end{array}$ & $\begin{array}{l}\text { Male } \\
\text { Rosa } a^{\mathrm{Cr}} / \mathrm{AMPKa} 1^{f l o x / f l o x} \mathrm{C} 57 \mathrm{BL} / 6 \\
\text { mice, and age-matched WT mice } \\
(2 \text { months old })\end{array}$ & [162] \\
\hline AMPK & Angelica sinensis & Vanillic acid (VA) & $\begin{array}{l}\text { inhibit adipogenic factors through } \\
\text { the AMPK pathway and decrease } \\
\text { lipid accumulation by suppressing } \\
\text { adipogenic factors }\end{array}$ & $\begin{array}{l}\text { Male C57BL/6J mice ( } 4 \text { weeks } \\
\text { old), Male } d b / d b \text { mice and age- } \\
\text { matched WT heterozygous mice( } 5 \\
\text { weeks old), Brown preadipocytes, } \\
\text { HepG } 2 \text { cells, 3T3-L1 cells, Primary } \\
\text { brown adipocytes }\end{array}$ & [163] \\
\hline AMPK & Many essential oils & Farnesol & $\begin{array}{l}\text { induce mitochondrial/peroxisomal } \\
\text { biogenesis and thermogenesis by } \\
\text { enhancing the AMPK Signalling }\end{array}$ & $\begin{array}{l}\text { Male C57BL/ } 6 \text { J mice }(4 / 7 \text { weeks } \\
\text { old), Brown preadipocytes }\end{array}$ & [164] \\
\hline
\end{tabular}




\begin{tabular}{|c|c|c|c|c|c|}
\hline Signalling pathways & Source & $\begin{array}{l}\text { Dietary } \\
\text { component }\end{array}$ & Mechanism of action & Models & Ref \\
\hline & & & pathway in BAT & & \\
\hline AMPK & $\begin{array}{l}\text { Many types of } \\
\text { plants, microalgae, } \\
\text { and some bacteria }\end{array}$ & $\begin{array}{l}\text { Gallic acid [3,4,5-trihydroxybenzoic acid } \\
\text { (GA)] }\end{array}$ & $\begin{array}{l}\text { elevate thermogenic gene } \\
\text { expressions and activate the } \\
\text { AMPK/Sirt1/PGC1a pathway in } \\
\text { interscapular brown adipose tissue }\end{array}$ & $\begin{array}{l}\text { HepG2 cells, Male C57BL/ } 6 \text { mice } \\
\text { (10-12 weeks old) }\end{array}$ & [165] \\
\hline AMPK & Rhubarb & Chrysophanic Acid & $\begin{array}{l}\text { activate the AMPK pathway and } \\
\text { then suppress adipogenesis and } \\
\text { induce thermogenesis }\end{array}$ & $\begin{array}{l}\text { Male C57BL/6J mice ( } 4 \text { weeks } \\
\text { old), 3T3-L1 preadipocytes, Brown } \\
\text { adipocytes }\end{array}$ & [166] \\
\hline NF-кB, TLR-4, AMPK & Green tea & (-)-Epigallocatechin-3-gallate (EGCG) & $\begin{array}{l}\text { raise mitochondrial biogenesis in } \\
\text { BAT; inhibit the NF-kB and STAT3 } \\
\text { pathways; increase the expression of } \\
\text { TLR- } 4 \text { by suppressing the expression } \\
\text { of Elf- } 1 \text {; increase mtDNA replication } \\
\text { and AMPK activation in BAT }\end{array}$ & $\begin{array}{l}\text { Male C57BL/6J mice (4 weeks } \\
\text { old), Male BALB/c mice ( } 8 \text { weeks } \\
\text { old), Peritoneal macrophages }\end{array}$ & [167-169] \\
\hline AMPK & $\begin{array}{l}\text { Many edible and } \\
\text { medicinal plants } \\
\text { such as pepper, } \\
\text { celery, thyme, } \\
\text { peppermint and } \\
\text { honeysuckle }\end{array}$ & Luteolin & $\begin{array}{l}\text { elevate thermogenic gene } \\
\text { expressions and activate } \\
\text { AMPK/PGC1a signalling in } \\
\text { differentiated primary brown and } \\
\text { subcutaneous adipocytes }\end{array}$ & $\begin{array}{l}\text { Male C57BL/ } 6 \text { mice ( } 4 \text { weeks old), } \\
\text { Primary brown adipocytes, } \\
\text { Subcutaneous adipocytes }\end{array}$ & {$[170]$} \\
\hline TRPA1, TRPV1 & Durian & $\begin{array}{l}\text { Sulphur-containing compounds (DEDS, } \\
\text { DPDS, DETS DPTS, and PT) }\end{array}$ & $\begin{array}{l}\text { induce } \mathrm{Ca}^{2+} \text { responses in TRPA1- or } \\
\text { TRPV1-expressing cells and then } \\
\text { activate both TRPA1 and TRPV1 }\end{array}$ & $\begin{array}{l}\text { Human TRPA1- or } \\
\text { TRPV1-expressing HEK cells }\end{array}$ & [125] \\
\hline TRP & Royal Jelly (RJ) & $\begin{array}{l}\text { 10-hydroxy-Trans- 2-decenoic acid } \\
\text { (HDEA) and Hydroxydecanoic acid } \\
\text { (HDAA) }\end{array}$ & $\begin{array}{l}\text { enhance thermogenic gene } \\
\text { expressions; activate the TRP } \\
\text { channels, specially TRPA1 in sensory } \\
\text { neurons of the gastrointestinal tract; } \\
\text { promote thermogenesis via } \\
\beta \text {-AR-mediated pathway in brown } \\
\text { and white adipocytes } \\
\text { (TRP-SNS-UCP1 axis) }\end{array}$ & Male Wistar rats ( 3 weeks old) & $\begin{array}{l}{[123,} \\
124]\end{array}$ \\
\hline
\end{tabular}

The AMPK signalling pathway is also involved in the BAT activation stimulated by many natural product ingredients, such as resveratrol, curcumin [134], EGCG [167] and berberine [154]. Resveratrol is a phenylpropanoid present in various foods including red cabbage, spinach, berries, red wine, and peanuts. Previous studies have suggested that resveratrol contributes to anti-obesity effects by activating the AMPK-SIRT1-PGC-1 $\alpha$ axis [171-174]. Recent research has also found that resveratrol promotes UCP1 expression and browning in a 338 MAPK-dependent but SIRT1-independent manner [175]. In addition, Hui, et al. reported that resveratrol partially enhances BAT activation and WAT browning via the gut microbiota-BA-TGR5/UCP1 pathway [176]. Many other natural product ingredients also promote thermogenesis through the AMPK signalling pathway, and we summarize them in Table 1.

Natural product ingredients that promote thermogenesis are involved in multiple and overlapping signalling pathways. The current research only scratches the surface. Further research is needed to understand the anti-obesity mechanism of natural products in terms of thermogenesis. A growing number of natural products, such as curcumin [134], thymol [145], magnolol [144] and albiflorin [146], have been shown to improve obesity by affecting the thermogenesis of brown adipose tissue through a variety of signalling pathways, and we will not go into detail here. With the development of methods and technologies, the mysteries of thermogenic pathways and their integration and control have begun to become apparent. Understanding human obesity, improving the chances of finding effective treatments and greatly reducing safety risks is crucial. Therefore, future research on thermogenesis in BAT will further develop our understanding of BAT physiology and therapeutic potential.

The mechanisms underlying the anti-obesity action of natural products are as complex as the mechanisms underlying the thermogenesis signalling pathway. We have confidence in natural products, which likely offer safer and more effective ways to treat obesity based on thermogenesis in the future.

\section{Conclusion and prospects}

Obesity is harmful to human health and leads to other diseases. Since the discovery of functional BAT in adults, targeting BAT has become a potential method to improve obesity and metabolic diseases. Further investigation of thermogenic signalling pathways is bound to apply to the treatment of obesity. Exploring the thermogenic signalling pathway is an important direction and approach to prevent obesity and related metabolism-related diseases.

However, further research is needed to clarify the importance and necessity of thermogenesis in humans and its potential applications in relation to the treatment of metabolism-related diseases. We have the following thoughts on future research on the 
signalling pathways related to thermogenesis:

1. Experiments studying the process by which certain pathways result in thermogenesis could be designed to discover regulators at committed steps of thermogenesis and BAT differentiation. Many signalling pathways, such as the mTOR pathway, have differential effects on thermogenesis which may be mediated via a noncell-autonomous mechanism and regulated by many upstream and downstream regulators. Therefore, it seems more reasonable to regulate the upstream and downstream regulators than to regulate the mTOR pathway directly.

2. The gut-brain-BAT axis may be an approach in the study of thermogenesis. Current understanding of the role of the gut-brain axis in energy balance regulation has received much attention and is a new direction in the treatment of obesity.

3. Study of the potential mechanism underlying inflammation in BAT thermogenesis is an important direction. Obesity is also a chronic systemic inflammation condition, and inflammatory pathways, such as the NF-kB pathway, are also involved in BAT thermogenesis and WAT browning. The interplay between inflammation and thermogenesis could lead to identification of novel signalling pathways.

4. The animal models and experimental systems used in the study of signalling pathways are the important basis. Different gene knockout mouse models may lead to radically different results, and the results from rodent studies are difficult to translate to human subjects. This requires discovery of other reliable animal models.

5. Research to reveal the specific mechanisms of age-related decreases in BAT could be a viable and effective way to recruit and activate human thermogenesis.

Nutraceutical targeting of BAT is by far the easiest and most likely effective method to treat obesity through thermogenesis. Application of natural medicines in obesity treatment is increasingly extensive, and research on the effect of natural products on BAT thermogenesis has gradually become a hot spot. Studying how natural ingredients affect thermogenic signalling pathways could lead to an understanding of the curative effects of natural ingredients on weight loss. However, it is undoubtedly complicated and difficult, and many questions remain.

1. Thermogenic signalling pathways interact with each other, and thus, the process is very complex. Moreover, the low specificity of drug targeting may lead to unexpected adverse reactions. Even the duration of action may lead to completely different outcomes. Much research is needed to explore the various signalling pathways and their interactions, and to better understand the mechanisms underlying the effects of natural products.

2. Currently, most natural products are available only as over-the-counter nutritional supplements, and there is a long way to go before they can be upgraded to pharmacological therapy.

3. Natural products are not sufficient as an acute, short-term, and safe medicine for obesity, and too many external factors affect long-term treatment with natural products. This is obviously unrealistic.

Therefore, much research is needed to explore the various signalling pathways involved in thermogenesis and their interactions, and to better understand the mechanisms underlying the effects of natural products.

\section{Abbreviations}

AMPK: AMP-activated protein kinase; ATF-2: activatingtranscriptionfactor-2; ATGL: adipose triglyceride lipase; AKT/cGMP: cyclic guanosine monophosphate; ANP: atrial natriuretic peptide; BNP: brain natriuretic peptide; BAT: brown adipose tissue; $\beta$-AR: $\beta$-adrenoceptor; CNP: C-type natriuretic peptide; cAMP: cyclic adenosine monophosphate; CEBPs: element-binding proteins; CNS: central nervous system; CPT1: carnitine palmitoyl transferase I; CD-NP: optimized designer natriuretic peptide; CREB: cAMP-response element binding protein; Dio2: Type II iodothyronine deiodinase; Dlk1: delta like non-canonical Notch ligand 1; eNOS: endothelial NO synthase; Elf-1: E74-like ETS transcription factor 1; FGF21: fibroblast growth factor 21; FA: fatty acid; Fox: Forkhead box; GLP-1: glucagon-like peptide 1; GC: guanylyl cyclases; GLUT: glucose transporter; HFD: high fat diet; HSL: hormone-sensitive triglyceride lipase; Hh: Hedgehog; HDAC3: histone deacetylase 3; IRE-1: inositol-requiring enzyme-1a; IRS: insulin receptor substrate; LSD1: lysine-specific demethylase 1; MCU: mitochondrial calcium uniporter; mTOR: mammalian target of rapamycin; NE: norepinephrine; NO: Noitric oxide; NP: natriuretic peptide; NPR: natriuretic peptide receptor; NF-kB: nuclear factor-Klight-chain-enhancer of activated $B$ cells; PDE: phosphodiesterase; PKA: protein kinase A; PLIN: Perilipin; PPARY: peroxisome proliferator-activated receptor $\gamma$; PGC1a: PPAR coactivator-1al; PRDM16: PR domain zinc finger protein; p38 MAPK: p38 mitogen-activated protein kinase; sGC: Soluble GC; Smad3-/-: Smad3 gene knockout; S6K: S6 kinase; SNS: sympathetic nervous system; SIRT: silent mating type information regulator 2 homolog; Tsc1/2: tuberous sclerosis complex $1 / 2$; TGF- $\beta /$ BMP: transforming growth factor- $\beta /$ bone morphogenic protein; TRP: transient receptor potential; TBX1: T-box transcription 
factor; UCP1: uncoupling protein 1; WAT: white adipose tissue; XBP-1: X-box binding protein-1.

\section{Acknowledgments}

\section{Funding}

This work was financially supported by the Science and Technology Program of Guangzhou, China (NO.202103000089), the Guangdong Demonstration Base for Joint Cultivation of Postgraduates, the Science Foundation for Distinguished Young Scholars of Guangdong (2020B1515020026).

\section{Author Contributions}

The authors' responsibilities were as follows - Zhengyan Zhang and Di Yang designed the review, Zhengyan Zhang and Di Yang drafted the manuscript, and all authors revised the literature, edited and approved the final submitted version of the manuscript.

\section{Competing Interests}

The authors have declared that no competing interest exists.

\section{References}

1. Ogden CL, Carroll MD, Kit BK, Flegal KM. Prevalence of childhood and adult obesity in the United States, 2011-2012. JAMA. 2014; 311: 806-14.

2. Cypess AM, Lehman S, Williams G, Tal I, Rodman D, Goldfine AB, et al. Identification and importance of brown adipose tissue in adult humans. $\mathrm{N}$ Engl J Med. 2009; 360: 1509-17.

3. Cannon B, Nedergaard J. Brown adipose tissue: function and physiological significance. Physiol Rev. 2004; 84: 277-359.

4. Kajimura S, Saito M. A new era in brown adipose tissue biology: molecular control of brown fat development and energy homeostasis. Annu Rev Physiol. 2014: 76: 225-49.

5. Dodd GT, Andrews ZB, Simonds SE, Michael NJ, DeVeer M, Bruning JC, et al. A Hypothalamic Phosphatase Switch Coordinates Energy Expenditure with Feeding. Cell Metab. 2017; 26: 375-93 e7.

6. Farmer SR. Transcriptional control of adipocyte formation. Cell Metab. 2006; 4: 263-73.

7. Puigserver P, Wu Z, Park CW, Graves R, Wright M, Spiegelman BM. A cold-inducible coactivator of nuclear receptors linked to adaptive thermogenesis. Cell. 1998; 92: 829-39.

8. Kajimura S, Seale P, Tomaru T, Erdjument-Bromage H, Cooper MP, Ruas JL, et al. Regulation of the brown and white fat gene programs through a PRDM16/CtBP transcriptional complex. Genes Dev. 2008; 22: 1397-409.

9. Chi J, Cohen P. The Multifaceted Roles of PRDM16: Adipose Biology and Beyond. Trends Endocrinol Metab. 2016; 27: 11-23.

10. Rajakumari S, Wu J, Ishibashi J, Lim HW, Giang AH, Won KJ, et al. EBF2 determines and maintains brown adipocyte identity. Cell Metab. 2013; 17: 562-74.

11. Villanueva CJ, Vergnes L, Wang J, Drew BG, Hong C, Tu Y, et al. Adipose subtype-selective recruitment of TLE3 or Prdm16 by PPARgamma specifies lipid storage versus thermogenic gene programs. Cell Metab. 2013; 17: 423-35.

12. Gan L, Liu Z, Feng F, Wu T, Luo D, Hu C, et al. Foxc2 coordinates inflammation and browning of white adipose by leptin-STAT3-PRDM16 signal in mice. Int J Obes (Lond). 2018; 42: 252-9.

13. Kajimura S, Seale P, Kubota K, Lunsford E, Frangioni JV, Gygi SP, et al. Initiation of myoblast to brown fat switch by a PRDM16-C/EBP-beta transcriptional complex. Nature. 2009; 460: 1154-8.

14. Robidoux J, Cao W, Quan H, Daniel KW, Moukdar F, Bai X, et al. Selective activation of mitogen-activated protein (MAP) kinase kinase 3 and p38alpha MAP kinase is essential for cyclic AMP-dependent UCP1 expression in adipocytes. Mol Cell Biol. 2005; 25: 5466-79.

15. Sanders MA, Madoux F, Mladenovic L, Zhang H, Ye X, Angrish M, et al. Endogenous and Synthetic ABHD5 Ligands Regulate ABHD5-Perilipin Interactions and Lipolysis in Fat and Muscle. Cell Metab. 2015; 22: 851-60.
16. Asada $R$, Kanemoto $S$, Matsuhisa $K$, Hino $K$, Cui $M$, Cui $X$ et al. IRE1alpha-XBP1 is a novel branch in the transcriptional regulation of Ucp1 in brown adipocytes. Sci Rep. 2015; 5: 16580.

17. Qiang L, Lin HV, Kim-Muller JY, Welch CL, Gu W, Accili D. Proatherogenic abnormalities of lipid metabolism in SirT1 transgenic mice are mediated through Creb deacetylation. Cell Metab. 2011; 14: 758-67.

18. Fan L, Ye H, Wan Y, Qin L, Zhu L, Su J, et al. Adaptor protein APPL1 coordinates HDAC3 to modulate brown adipose tissue thermogenesis in mice. Metabolism. 2019; 100: 153955.

19. Bo TB, Zhang XY, Wen J, Deng K, Qin XW, Wang DH. The microbiota-gut-brain interaction in regulating host metabolic adaptation to cold in male Brandt's voles (Lasiopodomys brandtii). ISME J. 2019; 13: 3037-53.

20. Shi $M$, Huang $X Y$, Ren $X Y$, Wei $X Y$, Ma $Y$, Lin $Z Z$, et al. AIDA directly connects sympathetic innervation to adaptive thermogenesis by UCP1. Nat Cell Biol. 2021; 23: 268-77.

21. Bai J, Cervantes C, He S, He J, Plasko GR, Wen J, et al. Mitochondrial stress-activated cGAS-STING pathway inhibits thermogenic program and contributes to overnutrition-induced obesity in mice. Commun Biol. 2020; 3: 257.

22. Lu H, Ye Z, Zhai Y, Wang L, Liu Y, Wang J, et al. QKI regulates adipose tissue metabolism by acting as a brake on thermogenesis and promoting obesity. EMBO Rep. 2020; 21: e47929.

23. Ceddia RP, Collins S. A compendium of G-protein-coupled receptors and cyclic nucleotide regulation of adipose tissue metabolism and energy expenditure. Clin Sci (Lond). 2020; 134: 473-512.

24. Palmer RM, Ferrige AG, Moncada S. Nitric oxide release accounts for the biological activity of endothelium-derived relaxing factor. Nature. 1987; 327: 524-6.

25. Lundberg JO, Gladwin MT, Ahluwalia A, Benjamin N, Bryan NS, Butler A, et al. Nitrate and nitrite in biology, nutrition and therapeutics. Nat Chem Biol. 2009; 5: 865-9.

26. Hoffmann LS, Etzrodt J, Willkomm L, Sanyal A, Scheja L, Fischer AWC, et al. Stimulation of soluble guanylyl cyclase protects against obesity by recruiting brown adipose tissue. Nat Commun. 2015; 6: 7235.

27. Becerril S, Rodriguez A, Catalan V, Sainz N, Ramirez B, Collantes M, et al. Deletion of inducible nitric-oxide synthase in leptin-deficient mice improves brown adipose tissue function. PLoS One. 2010; 5: e10962.

28. Dhamrait GK, Panchal K, Fleury NJ, Abel TN, Ancliffe MK, Crew RC, et al. Characterising nitric oxide-mediated metabolic benefits of low-dose ultraviolet radiation in the mouse: a focus on brown adipose tissue. Diabetologia. 2020; 63: 179-93.

29. Clementi E, Nisoli E. Nitric oxide and mitochondrial biogenesis: a key to long-term regulation of cellular metabolism. Comp Biochem Physiol A Mol Integr Physiol. 2005; 142: 102-10.

30. Ogawa T, de Bold AJ. The heart as an endocrine organ. Endocr Connect. 2014; 3: R31-44.

31. Ryden M, Backdahl J, Petrus P, Thorell A, Gao H, Coue M, et al. Impaired atrial natriuretic peptide-mediated lipolysis in obesity. Int J Obes (Lond). 2016; 40: 714-20.

32. Bordicchia M, Liu D, Amri EZ, Ailhaud G, Dessi-Fulgheri P, Zhang C, et al. Cardiac natriuretic peptides act via p38 MAPK to induce the brown fat thermogenic program in mouse and human adipocytes. J Clin Invest. 2012; 122: $1022-36$.

33. Carper D, Coue M, Nascimento EBM, Barquissau V, Lagarde D, Pestourie C, et al. Atrial Natriuretic Peptide Orchestrates a Coordinated Physiological Response to Fuel Non-shivering Thermogenesis. Cell Rep. 2020; 32: 108075.

34. Glode A, Naumann J, Gnad T, Cannone V, Kilic A, Burnett JC, Jr., et al. Divergent effects of a designer natriuretic peptide CD-NP in the regulation of adipose tissue and metabolism. Mol Metab. 2017; 6: 276-87.

35. Hardie DG. AMPK--sensing energy while talking to other signaling pathways. Cell Metab. 2014; 20: 939-52.

36. Hardie DG, Ross FA, Hawley SA. AMPK: a nutrient and energy sensor that maintains energy homeostasis. Nat Rev Mol Cell Biol. 2012; 13: 251-62.

37. Herzig S, Shaw RJ. AMPK: guardian of metabolism and mitochondrial homeostasis. Nat Rev Mol Cell Biol. 2018; 19: 121-35.

38. Zhao J, Yang Q, Zhang L, Liang X, Sun X, Wang B, et al. AMPKalpha1 deficiency suppresses brown adipogenesis in favor of fibrogenesis during brown adipose tissue development. Biochem Biophys Res Commun. 2017; 491: 508-14.

39. Wu L, Zhang L, Li B, Jiang H, Duan Y, Xie Z, et al. AMP-Activated Protein Kinase (AMPK) Regulates Energy Metabolism through Modulating Thermogenesis in Adipose Tissue. Front Physiol. 2018; 9: 122.

40. Wan Z, Root-McCaig J, Castellani L, Kemp BE, Steinberg GR, Wright DC. Evidence for the role of AMPK in regulating PGC-1 alpha expression and mitochondrial proteins in mouse epididymal adipose tissue. Obesity (Silver Spring). 2014; 22: 730-8.

41. Wright LE, Vecellio Reane D, Milan G, Terrin A, Di Bello G, Belligoli A, et al. Increased mitochondrial calcium uniporter in adipocytes underlies mitochondrial alterations associated with insulin resistance. Am J Physiol Endocrinol Metab. 2017; 313: E641-E50.

42. Gao P, Jiang Y, Wu H, Sun F, Li Y, He H, et al. Inhibition of Mitochondrial Calcium Overload by SIRT3 Prevents Obesity- or Age-Related Whitening of Brown Adipose Tissue. Diabetes. 2020; 69: 165-80. 
43. Minokoshi $\mathrm{Y}$, Alquier $\mathrm{T}$, Furukawa $\mathrm{N}$, Kim $\mathrm{YB}$, Lee $\mathrm{A}$, Xue $\mathrm{B}$, et al AMP-kinase regulates food intake by responding to hormonal and nutrient signals in the hypothalamus. Nature. 2004; 428: 569-74.

44. Namkoong C, Kim MS, Jang PG, Han SM, Park HS, Koh EH, et al. Enhanced hypothalamic AMP-activated protein kinase activity contributes to hyperphagia in diabetic rats. Diabetes. 2005; 54: 63-8.

45. Sjogren M, Alkemade A, Mittag J, Nordstrom K, Katz A, Rozell B, et al. Hypermetabolism in mice caused by the central action of an unliganded thyroid hormone receptor alpha1. EMBO J. 2007; 26: 4535-45.

46. Lopez M, Varela L, Vazquez MJ, Rodriguez-Cuenca S, Gonzalez CR, Velagapudi VR, et al. Hypothalamic AMPK and fatty acid metabolism mediate thyroid regulation of energy balance. Nat Med. 2010; 16: 1001-8.

47. Kooijman S, Wang Y, Parlevliet ET, Boon MR, Edelschaap D, Snaterse G, et al. Central GLP-1 receptor signalling accelerates plasma clearance of triacylglycerol and glucose by activating brown adipose tissue in mice. Diabetologia. 2015; 58: 2637-46.

48. Beiroa D, Imbernon M, Gallego R, Senra A, Herranz D, Villarroya F, et al. GLP-1 agonism stimulates brown adipose tissue thermogenesis and browning through hypothalamic AMPK. Diabetes. 2014; 63: 3346-58

49. Zhou J, Poudel A, Chandramani-Shivalingappa P, Xu B, Welchko R, Li L. Liraglutide induces beige fat development and promotes mitochondrial function in diet induced obesity mice partially through AMPK-SIRT-1-PGC1-alpha cell signaling pathway. Endocrine. 2019; 64: 271-83.

50. Seoane-Collazo P, Roa J, Rial-Pensado E, Linares-Pose L, Beiroa D, Ruiz-Pino F, et al. SF1-Specific AMPKalpha1 Deletion Protects Against Diet-Induced Obesity. Diabetes. 2018; 67: 2213-26

51. Laplante M, Sabatini DM. mTOR signaling in growth control and disease. Cell. 2012; 149: 274-93.

52. Couso I, Evans BS, Li J, Liu Y, Ma F, Diamond S, et al. Synergism between Inositol Polyphosphates and TOR Kinase Signaling in Nutrient Sensing, Growth Control, and Lipid Metabolism in Chlamydomonas. Plant Cell. 2016; 28: 2026-42.

53. Cai H, Dong LQ, Liu F. Recent Advances in Adipose mTOR Signaling and Function: Therapeutic Prospects. Trends Pharmacol Sci. 2016; 37: 303-17.

54. Ye Y, Liu H, Zhang F, Hu F. mTOR signaling in Brown and Beige adipocytes: implications for thermogenesis and obesity. Nutr Metab (Lond). 2019; 16: 74

55. Zhang X, Wu D, Wang C, Luo Y, Ding X, Yang X, et al. Sustained activation of autophagy suppresses adipocyte maturation via a lipolysis-dependent mechanism. Autophagy. 2020; 16: 1668-82.

56. Polak P, Cybulski N, Feige JN, Auwerx J, Ruegg MA, Hall MN. Adipose-specific knockout of raptor results in lean mice with enhanced mitochondrial respiration. Cell Metab. 2008; 8: 399-410.

57. Zhang $X$, Luo $Y$, Wang $C$, Ding $X$, Yang $X, W u$ D, et al. Adipose mTORC1 Suppresses Prostaglandin Signaling and Beige Adipogenesis via the CRTC2-COX-2 Pathway. Cell Rep. 2018; 24: 3180-93.

58. Lee PL, Tang Y, Li H, Guertin DA. Raptor/mTORC1 loss in adipocytes causes progressive lipodystrophy and fatty liver disease. Mol Metab. 2016; 5: 422-32.

59. Xiang $\mathrm{X}$, Lan $\mathrm{H}$, Tang $\mathrm{H}$, Yuan $\mathrm{F}, \mathrm{Xu} \mathrm{Y}$, Zhao J, et al. Tuberous sclerosis complex 1-mechanistic target of rapamycin complex 1 signaling determines brown-to-white adipocyte phenotypic switch. Diabetes. 2015; 64: 519-28.

60. Olsen JM, Csikasz RI, Dehvari N, Lu L, Sandstrom A, Oberg AI, et al. beta3-Adrenergically induced glucose uptake in brown adipose tissue is independent of UCP1 presence or activity: Mediation through the mTOR pathway. Mol Metab. 2017; 6: 611-9.

61. Liu M, Bai J, He S, Villarreal R, Hu D, Zhang C, et al. Grb10 promotes lipolysis and thermogenesis by phosphorylation-dependent feedback inhibition of mTORC1. Cell Metab. 2014; 19: 967-80.

62. Um SH, Frigerio F, Watanabe M, Picard F, Joaquin M, Sticker M, et al. Absence of S6K1 protects against age- and diet-induced obesity while enhancing insulin sensitivity. Nature. 2004; 431: 200-5.

63. Liu D, Ceddia RP, Collins S. Cardiac natriuretic peptides promote adipose 'browning' through mTOR complex-1. Mol Metab. 2018; 9: 192-8.

64. Yang K, Cai J, Pan M, Sun Q, Sun C. Mark4 Inhibited the Browning of White Adipose Tissue by Promoting Adipocytes Autophagy in Mice. Int J Mol Sci. 2020; 21.

65. Yau WW, Singh BK, Lesmana R, Zhou J, Sinha RA, Wong KA, et al. Thyroid hormone (T3) stimulates brown adipose tissue activation via mitochondrial biogenesis and MTOR-mediated mitophagy. Autophagy. 2019; 15: 131-50.

66. Przygodda F, Lautherbach N, Buzelle SL, Goncalves DA, Assis AP, Paula-Gomes $\mathrm{S}$, et al. Sympathetic innervation suppresses the autophagic-lysosomal system in brown adipose tissue under basal and cold-stimulated conditions. J Appl Physiol (1985). 2020; 128: 855-71.

67. Albert V, Svensson K, Shimobayashi M, Colombi M, Munoz S, Jimenez V, et al. mTORC2 sustains thermogenesis via Akt-induced glucose uptake and glycolysis in brown adipose tissue. EMBO Mol Med. 2016; 8: 232-46.

68. Olsen JM, Sato M, Dallner OS, Sandstrom AL, Pisani DF, Chambard JC, et al. Glucose uptake in brown fat cells is dependent on mTOR complex 2-promoted GLUT1 translocation. J Cell Biol. 2014; 207: 365-74.

69. Jung SM, Hung CM, Hildebrand SR, Sanchez-Gurmaches J, Martinez-Pastor B, Gengatharan JM, et al. Non-canonical mTORC2 Signaling Regulates Brown Adipocyte Lipid Catabolism through SIRT6-FoxO1. Mol Cell. 2019; 75: 807-22 e8.

70. Nickel J, Ten Dijke P, Mueller TD. TGF-beta family co-receptor function and signaling. Acta Biochim Biophys Sin (Shanghai). 2018; 50: 12-36.
71. Yadav $\mathrm{H}$, Quijano $\mathrm{C}$, Kamaraju AK, Gavrilova $\mathrm{O}$, Malek $\mathrm{R}$, Chen W, et al. Protection from obesity and diabetes by blockade of TGF-beta/Smad3 signaling. Cell Metab. 2011; 14: 67-79.

72. Wankhade UD, Lee JH, Dagur PK, Yadav H, Shen M, Chen W, et al. TGF-beta receptor 1 regulates progenitors that promote browning of white fat. Mol Metab. 2018; 16: 160-71.

73. Pervin S, Reddy ST, Singh R. Novel Roles of Follistatin/Myostatin in Transforming Growth Factor-beta Signaling and Adipose Browning: Potential for Therapeutic Intervention in Obesity Related Metabolic Disorders. Front Endocrinol (Lausanne). 2021; 12: 653179.

74. Hoffmann JM, Grunberg JR, Hammarstedt A, Kroon T, Greiner TU, Maurer S, et al. BMP4 gene therapy enhances insulin sensitivity but not adipose tissue browning in obese mice. Mol Metab. 2020; 32: 15-26.

75. Martins L, Seoane-Collazo P, Contreras C, Gonzalez-Garcia I, Martinez-Sanchez N, Gonzalez F, et al. A Functional Link between AMPK and Orexin Mediates the Effect of BMP8B on Energy Balance. Cell Rep. 2016; 16: 2231-42.

76. Blazquez-Medela AM, Jumabay M, Rajbhandari P, Sallam T, Guo Y, Yao J, et al. Noggin depletion in adipocytes promotes obesity in mice. Mol Metab. 2019; 25: 50-63.

77. Li H TRP Channel Classification. Adv Exp Med Biol. 2017: 976: 1-8.

78. Earley S, Brayden JE. Transient receptor potential channels in the vasculature. Physiol Rev. 2015; 95: 645-90.

79. Baskaran P, Krishnan V, Fettel K, Gao P, Zhu Z, Ren J, et al. TRPV1 activation counters diet-induced obesity through sirtuin-1 activation and PRDM-16 deacetylation in brown adipose tissue. Int J Obes (Lond). 2017; 41: 739-49.

80. Conceicao EPS, Reynolds CA, Morrison SF, Madden CJ. Activation of Transient Receptor Potential Vanilloid 1 Channels in the Nucleus of the Solitary Tract and Activation of Dynorphin Input to the Median Preoptic Nucleus Contribute to Impaired BAT Thermogenesis in Diet-Induced Obesity. eNeuro. 2021; 8 .

81. Sun W, Uchida K, Takahashi N, Iwata Y, Wakabayashi S, Goto T, et al. Activation of TRPV2 negatively regulates the differentiation of mouse brown adipocytes. Pflugers Arch. 2016; 468: 1527-40.

82. Uchida K, Dezaki K, Yoneshiro T, Watanabe T, Yamazaki J, Saito M, et al. Involvement of thermosensitive TRP channels in energy metabolism. J Physiol Sci. 2017; 67: 549-60.

83. Sun $\mathrm{W}$, Uchida $\mathrm{K}$, Tominaga $\mathrm{M}$. TRPV2 regulates BAT thermogenesis and differentiation. Channels (Austin). 2017; 11: 94-6.

84. Sun W, Uchida K, Suzuki Y, Zhou Y, Kim M, Takayama Y, et al. Lack of TRPV2 impairs thermogenesis in mouse brown adipose tissue. EMBO Rep. 2016; 17: 383-99.

85. de la Pena E, Malkia A, Cabedo H, Belmonte C, Viana F. The contribution of TRPM8 channels to cold sensing in mammalian neurones. J Physiol. 2005; 567: 115-26.

86. Sanders OD, Rajagopal JA, Rajagopal L. Menthol to Induce Non-shivering Thermogenesis via TRPM8/PKA Signaling for Treatment of Obesity. J Obes Metab Syndr. 2021; 30: 4-11.

87. Goralczyk A, van Vijven M, Koch M, Badowski C, Yassin MS, Toh SA, et al. TRP channels in brown and white adipogenesis from human progenitors: new therapeutic targets and the caveats associated with the common antibiotic, streptomycin. FASEB J. 2017; 31: 3251-66.

88. Moraes MN, de Assis LVM, Henriques FDS, Batista ML, Jr., Guler AD, Castrucci AML. Cold-sensing TRPM8 channel participates in circadian control of the brown adipose tissue. Biochim Biophys Acta Mol Cell Res. 2017; 1864: 2415-27.

89. Wolfrum C, Kiehlmann E, Pelczar P. TRPC1 regulates brown adipose tissue activity in a PPARgamma-dependent manner. Am J Physiol Endocrinol Metab. 2018; 315: E825-E32.

90. Bi P, Kuang S. Notch signaling as a novel regulator of metabolism. Trends Endocrinol Metab. 2015; 26: 248-55.

91. Boucher JM, Ryzhova L, Harrington A, Davis-Knowlton J, Turner JE, Cooper E, et al. Pathological Conversion of Mouse Perivascular Adipose Tissue by Notch Activation. Arterioscler Thromb Vasc Biol. 2020; 40: 2227-43.

92. Bi P, Shan T, Liu W, Yue F, Yang X, Liang XR, et al. Inhibition of Notch signaling promotes browning of white adipose tissue and ameliorates obesity. Nat Med. 2014; 20: 911-8

93. Huang D, Narayanan N, Cano-Vega MA, Jia Z, Ajuwon KM, Kuang S, et al. Nanoparticle-Mediated Inhibition of Notch Signaling Promotes Mitochondrial Biogenesis and Reduces Subcutaneous Adipose Tissue Expansion in Pigs. iScience. 2020; 23: 101167

94. Meng W, Liang X, Xiao T, Wang J, Wen J, Luo H, et al. Rheb promotes brown fat thermogenesis by Notch-dependent activation of the PKA signaling pathway. J Mol Cell Biol. 2019; 11: 781-90.

95. Suh JM, Gao X, McKay J, McKay R, Salo Z, Graff JM. Hedgehog signaling plays a conserved role in inhibiting fat formation. Cell Metab. 2006; 3: 25-34.

96. Nosavanh L, Yu DH, Jaehnig EJ, Tong Q, Shen L, Chen MH. Cell-autonomous activation of Hedgehog signaling inhibits brown adipose tissue development. Proc Natl Acad Sci U S A. 2015; 112: 5069-74.

97. Wang J, Ge J, Cao H, Zhang X, Guo Y, Li X, et al. Leptin Promotes White Adipocyte Browning by Inhibiting the Hh Signaling Pathway. Cells. 2019; 8.

98. Zhang X, Cheng Q, Wang Y, Leung PS, Mak KK. Hedgehog signaling in bone regulates whole-body energy metabolism through a bone-adipose endocrine relay mediated by PTHrP and adiponectin. Cell Death Differ. 2017; 24: 225-37. 
99. Kang S, Bajnok L, Longo KA, Petersen RK, Hansen JB, Kristiansen K, et al. Effects of Wnt signaling on brown adipocyte differentiation and metabolism mediated by PGC-1alpha. Mol Cell Biol. 2005; 25: 1272-82.

100. Tseng YH, Butte AJ, Kokkotou E, Yechoor VK, Taniguchi CM, Kriauciunas $\mathrm{KM}$, et al. Prediction of preadipocyte differentiation by gene expression reveals role of insulin receptor substrates and necdin. Nat Cell Biol. 2005; 7: $601-11$

101. Lo KA, Ng PY, Kabiri Z, Virshup D, Sun L. Wnt inhibition enhances browning of mouse primary white adipocytes. Adipocyte. 2016; 5: 224-31.

102. Chen Y, Kim J, Zhang R, Yang X, Zhang Y, Fang J, et al. Histone Demethylase LSD1 Promotes Adipocyte Differentiation through Repressing Wnt Signaling. Cell Chem Biol. 2016; 23: 1228-40.

103. Cantwell MT, Farrar JS, Lownik JC, Meier JA, Hyun M, Raje V, et al. STAT3 suppresses $\mathrm{Wnt} /$ beta-catenin signaling during the induction phase of primary Myf5+ brown adipogenesis. Cytokine. 2018; 111: 434-44.

104. Karin M, Cao Y, Greten FR, Li ZW. NF-kappaB in cancer: from innocent bystander to major culprit. Nat Rev Cancer. 2002; 2: 301-10.

105. Zhang X, Zhang G, Zhang H, Karin M, Bai H, Cai D. Hypothalamic IKKbeta/NF-kappaB and ER stress link overnutrition to energy imbalance and obesity. Cell. 2008; 135: 61-73.

106. Mauro C, Leow SC, Anso E, Rocha S, Thotakura AK, Tornatore L, et al. NF-kappaB controls energy homeostasis and metabolic adaptation by upregulating mitochondrial respiration. Nat Cell Biol. 2011; 13: 1272-9.

107. Shahid M, Javed AA, Chandra D, Ramsey HE, Shah D, Khan MF, et al. IEX-1 deficiency induces browning of white adipose tissue and resists diet-induced obesity. Sci Rep. 2016; 6: 24135.

108. Cao W, Huang H, Xia T, Liu C, Muhammad S, Sun C. Homeobox a5 Promotes White Adipose Tissue Browning Through Inhibition of the Tenascin C/Toll-Like Receptor 4/Nuclear Factor Kappa B Inflammatory Signaling in Mice. Front Immunol. 2018; 9: 647.

109. Okamatsu-Ogura Y, Kuroda M, Tsutsumi R, Tsubota A, Saito M, Kimura K, et al. UCP1-dependent and UCP1-independent metabolic changes induced by acute cold exposure in brown adipose tissue of mice. Metabolism. 2020; 113: 154396.

110. Wang Z, Ning T, Song A, Rutter J, Wang QA, Jiang L. Chronic cold exposure enhances glucose oxidation in brown adipose tissue. EMBO Rep. 2020; 21: e50085.

111. Lee P, Smith S, Linderman J, Courville AB, Brychta RJ, Dieckmann W, et al. Temperature-acclimated brown adipose tissue modulates insulin sensitivity in humans. Diabetes. 2014; 63: 3686-98.

112. Dong M, Yang X, Lim S, Cao Z, Honek J, Lu H, et al. Cold exposure promotes atherosclerotic plaque growth and instability via UCP1-dependent lipolysis. Cell Metab. 2013; 18: 118-29.

113. O'Mara AE, Johnson JW, Linderman JD, Brychta RJ, McGehee S, Fletcher LA, et al. Chronic mirabegron treatment increases human brown fat, HDL cholesterol, and insulin sensitivity. J Clin Invest. 2020.

114. Sui W, Li H, Yang Y, Jing X, Xue F, Cheng J, et al. Bladder drug mirabegron exacerbates atherosclerosis through activation of brown fat-mediated lipolysis. Proc Natl Acad Sci U S A. 2019; 116: 10937-42.

115. Tu WZ, Fu YB, Xie X. RepSox, a small molecule inhibitor of the TGFbeta receptor, induces brown adipogenesis and browning of white adipocytes. Acta Pharmacol Sin. 2019; 40: 1523-31.

116. Krishnan V, Baskaran P, Thyagarajan B. Troglitazone activates TRPV1 and causes deacetylation of PPARgamma in 3T3-L1 cells. Biochim Biophys Acta Mol Basis Dis. 2019; 1865: 445-53.

117. Fang Y, Westbrook R, Hill C, Boparai RK, Arum O, Spong A, et al. Duration of rapamycin treatment has differential effects on metabolism in mice. Cell Metab. 2013; 17: 456-62.

118. Bakhtiarzadeh F, Siavoshi F, Gheibi S, Kashfi K, Samadi R, Jeddi S, et al. Effects of long-term oral nitrate administration on adiposity in normal adult female rats. Life Sci. 2018; 210: 76-85.

119. Saito M, Matsushita M, Yoneshiro T, Okamatsu-Ogura Y. Brown Adipose Tissue, Diet-Induced Thermogenesis, and Thermogenic Food Ingredients: From Mice to Men. Front Endocrinol (Lausanne). 2020; 11: 222.

120. Ono K, Tsukamoto-Yasui M, Hara-Kimura Y, Inoue N, Nogusa Y, Okabe Y, et al. Intragastric administration of capsiate, a transient receptor potential channel agonist, triggers thermogenic sympathetic responses. J Appl Physiol (1985). 2011; 110: 789-98.

121. Kawada T, Watanabe T, Takaishi T, Tanaka T, Iwai K. Capsaicin-induced beta-adrenergic action on energy metabolism in rats: influence of capsaicin on oxygen consumption, the respiratory quotient, and substrate utilization. Proc Soc Exp Biol Med. 1986; 183: 250-6.

122. Baskaran P, Krishnan V, Ren J, Thyagarajan B. Capsaicin induces browning of white adipose tissue and counters obesity by activating TRPV1 channel-dependent mechanisms. Br J Pharmacol. 2016; 173: 2369-89.

123. Mesri Alamdari N, Irandoost P, Roshanravan N, Vafa M, Asghari Jafarabadi M, Alipour S, et al. Effects of Royal Jelly and Tocotrienol Rich Fraction in obesity treatment of calorie-restricted obese rats: a focus on white fat browning properties and thermogenic capacity. Nutr Metab (Lond). 2020; 17: 42

124. Terada $Y$, Narukawa M, Watanabe T. Specific hydroxy fatty acids in royal jelly activate TRPA1. J Agric Food Chem. 2011; 59: 2627-35.

125. Terada $Y$, Hosono $T$, Seki $T$, Ariga $T$, Ito $S$, Narukawa $M$, et al. Sulphur-containing compounds of durian activate the thermogenesis-inducing receptors TRPA1 and TRPV1. Food Chem. 2014; 157: 213-20.

126. Jiang J, Emont MP, Jun H, Qiao X, Liao J, Kim DI, et al. Cinnamaldehyde induces fat cell-autonomous thermogenesis and metabolic reprogramming. Metabolism. 2017; 77: 58-64

127. Khare P, Chauhan A, Kumar V, Kaur J, Mahajan N, Kumar V, et al. Bioavailable Menthol (Transient Receptor Potential Melastatin-8 Agonist) Induces Energy Expending Phenotype in Differentiating Adipocytes. Cells. $2019 ; 8$.

128. Masamoto $\mathrm{Y}$, Kawabata F, Fushiki T. Intragastric administration of TRPV1, TRPV3, TRPM8, and TRPA1 agonists modulates autonomic thermoregulation in different manners in mice. Biosci Biotechnol Biochem. 2009; 73: 1021-7.

129. Jiang L, Dong H, Meng Q, Li H, He M, Wei Z, et al. Millimeter-sized molecular monolayer two-dimensional crystals. Adv Mater. 2011; 23: 2059-63.

130. Lee K, Jin H, Chei S, Oh HJ, Choi SH, Nah SY, et al. The Gintonin-Enriched Fraction of Ginseng Regulates Lipid Metabolism and Browning via the cAMP-Protein Kinase a Signaling Pathway in Mice White Adipocytes. Biomolecules. 2020; 10

131. Chen PH, Chen GC, Yang MF, Hsieh CH, Chuang SH, Yang HL, et al. Bitter melon seed oil-attenuated body fat accumulation in diet-induced obese mice is associated with cAMP-dependent protein kinase activation and cell death in white adipose tissue. J Nutr. 2012; 142: 1197-204.

132. Bae IS, Kim SH. Sinapic Acid Promotes Browning of 3T3-L1 Adipocytes via p38 MAPK/CREB Pathway. Biomed Res Int. 2020; 2020: 5753623.

133. Hossain M, Imran KM, Rahman MS, Yoon D, Marimuthu V, Kim YS. Sinapic acid induces the expression of thermogenic signature genes and lipolysis through activation of PKA/CREB signaling in brown adipocytes. BMB Rep. 2020; 53: 142-7.

134. Zhao D, Pan Y, Yu N, Bai Y, Ma R, Mo F, et al. Curcumin improves adipocytes browning and mitochondrial function in 3T3-L1 cells and obese rodent model. R Soc Open Sci. 2021; 8: 200974.

135. Song Z, Revelo X, Shao W, Tian L, Zeng K, Lei H, et al. Dietary Curcumin Intervention Targets Mouse White Adipose Tissue Inflammation and Brown Adipose Tissue UCP1 Expression. Obesity (Silver Spring). 2018; 26: 547-58.

136. Lone J, Choi JH, Kim SW, Yun JW. Curcumin induces brown fat-like phenotype in 3T3-L1 and primary white adipocytes. J Nutr Biochem. 2016; 27: 193-202.

137. Zingg JM, Hasan ST, Nakagawa K, Canepa E, Ricciarelli R, Villacorta L, et al. Modulation of cAMP levels by high-fat diet and curcumin and regulatory effects on CD36/FAT scavenger receptor/fatty acids transporter gene expression. Biofactors. 2017; 43: 42-53.

138. Rahman MS, Kim YS. PINK1-PRKN mitophagy suppression by mangiferin promotes a brown-fat-phenotype via PKA-p38 MAPK signalling in murine C3H10T1/2 mesenchymal stem cells. Metabolism. 2020; 107: 154228.

139. Rahman MS, Kim YS. Mangiferin induces the expression of a thermogenic signature via AMPK signaling during brown-adipocyte differentiation. Food Chem Toxicol. 2020; 141: 111415.

140. Moon Y, Tong T, Kang W, Park T. Filbertone Ameliorates Adiposity in Mice Fed a High-Fat Diet via Activation of cAMP Signaling. Nutrients. 2019; 11.

141. Pei Y, Otieno D, Gu I, Lee SO, Parks JS, Schimmel K, et al. Effect of quercetin on nonshivering thermogenesis of brown adipose tissue in high-fat diet-induced obese mice. J Nutr Biochem. 2020; 88: 108532.

142. Seo YJ, Lee K, Chei S, Jeon YJ, Lee BY. Ishige okamurae Extract Ameliorates the Hyperglycemia and Body Weight Gain of $\mathrm{db} / \mathrm{db}$ Mice through Regulation of the PI3K/Akt Pathway and Thermogenic Factors by FGF21. Mar Drugs. $2019 ; 17$.

143. Kang NH, Mukherjee S, Min T, Kang SC, Yun JW. Trans-anethole ameliorates obesity via induction of browning in white adipocytes and activation of brown adipocytes. Biochimie. 2018; 151: 1-13.

144. Parray HA, Lone J, Park JP, Choi JW, Yun JW. Magnolol promotes thermogenesis and attenuates oxidative stress in 3T3-L1 adipocytes. Nutrition. 2018; 50: 82-90.

145. Choi JH, Kim SW, Yu R, Yun JW. Monoterpene phenolic compound thymol promotes browning of 3T3-L1 adipocytes. Eur J Nutr. 2017; 56: 2329-41.

146. Jeong MY, Park J, Youn DH, Jung Y, Kang J, Lim S, et al. Albiflorin ameliorates obesity by inducing thermogenic genes via AMPK and PI3K/AKT in vivo and in vitro. Metabolism. 2017; 73: 85-99.

147. Chu S, Narayan VP, Sung MK, Park T. Piperonal attenuates visceral adiposity in mice fed a high-fat diet: potential involvement of the adenylate cyclase-protein kinase A dependent pathway. Mol Nutr Food Res. 2017; 61.

148. Kim N, Nam M, Kang MS, Lee JO, Lee YW, Hwang GS, et al. Piperine regulates UCP1 through the AMPK pathway by generating intracellular lactate production in muscle cells. Sci Rep. 2017; 7: 41066.

149. Xu Y, Wang N, Tan HY, Li S, Zhang C, Zhang Z, et al. Panax notoginseng saponins modulate the gut microbiota to promote thermogenesis and beige adipocyte reconstruction via leptin-mediated AMPKalpha/STAT3 signaling in diet-induced obesity. Theranostics. 2020; 10: 11302-23.

150. Kang J, Park J, Park WY, Jiao W, Lee S, Jung Y, et al. A phytoestrogen secoisolariciresinol diglucoside induces browning of white adipose tissue and activates non-shivering thermogenesis through AMPK pathway. Pharmacol Res. 2020; 158: 104852.

151. Park J, Kim HL, Jung Y, Ahn KS, Kwak HJ, Um JY. Bitter Orange (Citrus aurantium Linne) Improves Obesity by Regulating Adipogenesis and Thermogenesis through AMPK Activation. Nutrients. 2019; 11. 
152. Sun YS, Qu W. Dietary Apigenin promotes lipid catabolism, thermogenesis, and browning in adipose tissues of HFD-Fed mice. Food Chem Toxicol. 2019; 133: 110780 .

153. Wang J, Li D, Wang $\mathrm{P}, \mathrm{Hu} \mathrm{X}$, Chen F. Ginger prevents obesity through regulation of energy metabolism and activation of browning in high-fat diet-induced obese mice. J Nutr Biochem. 2019; 70: 105-15.

154. Wu L, Xia M, Duan Y, Zhang L, Jiang H, Hu X, et al. Berberine promotes the recruitment and activation of brown adipose tissue in mice and humans. Cell Death Dis. 2019; 10: 468.

155. Zhang Z, Zhang H, Li B, Meng X, Wang J, Zhang Y, et al. Berberine activates thermogenesis in white and brown adipose tissue. Nat Commun. 2014; 5: 5493.

156. Palacios-Gonzalez B, Vargas-Castillo A, Velazquez-Villegas LA, Vasquez-Reyes S, Lopez P, Noriega LG, et al. Genistein increases the thermogenic program of subcutaneous WAT and increases energy expenditure in mice. J Nutr Biochem. 2019; 68: 59-68.

157. Jung TW, Kim HC, Shin YK, Min H, Cho SW, Kim ZS, et al. Humulus japonicus stimulates thermogenesis and ameliorates oxidative stress in mouse adipocytes. J Mol Endocrinol. 2019; 63: 1-9.

158. Kim KD, Jung HY, Ryu HG, Kim B, Jeon J, Yoo HY, et al. Betulinic acid inhibits high-fat diet-induced obesity and improves energy balance by activating AMPK. Nutr Metab Cardiovasc Dis. 2019; 29: 409-20.

159. Qi G, Zhou Y, Zhang X, Yu J, Li X, Cao X, et al. Cordycepin promotes browning of white adipose tissue through an AMP-activated protein kinase (AMPK)-dependent pathway. Acta Pharm Sin B. 2019; 9: 135-43.

160. Kim HL, Park J, Jung Y, Ahn KS, Um JY. Platycodin D, a novel activator of AMP-activated protein kinase, attenuates obesity in $\mathrm{db} / \mathrm{db}$ mice via regulation of adipogenesis and thermogenesis. Phytomedicine. 2019; 52: 254-63.

161. Samuels JS, Shashidharamurthy R, Rayalam S. Novel anti-obesity effects of beer hops compound xanthohumol: role of AMPK signaling pathway. Nutr Metab (Lond). 2018; 15: 42.

162. Zou T, Wang B, Yang Q, de Avila JM, Zhu MJ, You J, et al. Raspberry promotes brown and beige adipocyte development in mice fed high-fat diet through activation of AMP-activated protein kinase (AMPK) alpha1. J Nutr Biochem. 2018; 55: 157-64.

163. Jung Y, Park J, Kim HL, Sim JE, Youn DH, Kang J, et al. Vanillic acid attenuates obesity via activation of the AMPK pathway and thermogenic factors in vivo and in vitro. FASEB J. 2018; 32: 1388-402.

164. Cho SY, Lim S, Ahn KS, Kwak HJ, Park J, Um JY. Farnesol induces mitochondrial/peroxisomal biogenesis and thermogenesis by enhancing the AMPK signaling pathway in vivo and in vitro. Pharmacol Res. 2020; 163: 105312.

165. Doan KV, Ko CM, Kinyua AW, Yang DJ, Choi YH, Oh IY, et al. Gallic acid regulates body weight and glucose homeostasis through AMPK activation. Endocrinology. 2015; 156: 157-68.

166. Lim H, Park J, Kim HL, Kang J, Jeong MY, Youn DH, et al. Chrysophanic Acid Suppresses Adipogenesis and Induces Thermogenesis by Activating AMP-Activated Protein Kinase Alpha In vivo and In vitro. Front Pharmacol. 2016; 7: 476.

167. Zhou J, Mao L, Xu P, Wang Y. Effects of (-)-Epigallocatechin Gallate (EGCG) on Energy Expenditure and Microglia-Mediated Hypothalamic Inflammation in Mice Fed a High-Fat Diet. Nutrients. 2018; 10.

168. Kumazoe M, Yamashita M, Nakamura Y, Takamatsu K, Bae J, Yamashita S, et al. Green Tea Polyphenol EGCG Upregulates Tollip Expression by Suppressing Elf-1 Expression. J Immunol. 2017; 199: 3261-9.

169. Lee MS, Shin Y, Jung S, Kim Y. Effects of epigallocatechin-3-gallate on thermogenesis and mitochondrial biogenesis in brown adipose tissues of diet-induced obese mice. Food Nutr Res. 2017; 61: 1325307.

170. Zhang X, Zhang QX, Wang X, Zhang L, Qu W, Bao B, et al. Dietary luteolin activates browning and thermogenesis in mice through an AMPK/PGC1alpha pathway-mediated mechanism. Int J Obes (Lond). 2016; 40: 1841-9.

171. Baur JA, Pearson KJ, Price NL, Jamieson HA, Lerin C, Kalra A, et al. Resveratrol improves health and survival of mice on a high-calorie diet. Nature. 2006; 444: 337-42.

172. Lagouge M, Argmann C, Gerhart-Hines Z, Meziane H, Lerin C, Daussin F, et al. Resveratrol improves mitochondrial function and protects against metabolic disease by activating SIRT1 and PGC-1alpha. Cell. 2006; 127: 1109-22.

173. Cheang WS, Wong WT, Wang L, Cheng CK, Lau CW, Ma RCW, et al. Resveratrol ameliorates endothelial dysfunction in diabetic and obese mice through sirtuin 1 and peroxisome proliferator-activated receptor delta. Pharmacol Res. 2019; 139: 384-94.

174. Wang S, Liang X, Yang Q, Fu X, Zhu M, Rodgers BD, et al. Resveratrol enhances brown adipocyte formation and function by activating AMP-activated protein kinase (AMPK) alpha1 in mice fed high-fat diet. Mol Nutr Food Res. 2017; 61.

175. Ravaud C, Pare M, Yao X, Azoulay S, Mazure NM, Dani C, et al. Resveratrol and HIV-protease inhibitors control UCP1 expression through opposite effects on p38 MAPK phosphorylation in human adipocytes. J Cell Physiol. 2020; 235: 1184-96.

176. Hui S, Liu Y, Huang L, Zheng L, Zhou M, Lang H, et al. Resveratrol enhances brown adipose tissue activity and white adipose tissue browning in part by regulating bile acid metabolism via gut microbiota remodeling. Int J Obes (Lond). 2020. 